\title{
New species of Deinogalerix (Mammalia, Eulipotyphla) from the late Miocene of Scontrone (Abruzzo, central Italy)
}

\author{
Andrea Savorelli, Federico Masini, Paul P. A. Mazza, \\ Maria Adelaide Rossi, and Silvano Agostini
}

\begin{abstract}
Deinogalerix is a typical component of the late Miocene insular fauna of Gargano (south-eastern Italy). Remains of this taxon had also been found over the last 20 years at the early Tortonian site of Scontrone (Abruzzo, central Italy), but they had never been described in detail. Two new species are introduced. One of them, $D$. samniticus sp. nov., is larger sized and better documented, and received a formal description. The other entity is clearly distinct from $D$. samniticus sp. nov., but it is merely represented by a single mandible. It is therefore presented here as a different, but undetermined species, Deinogalerix sp. Comparative analyses show that the new species have exclusive dental proportions that distinguish them from all the other species of Deinogalerix and seem to exclude them from the direct ancestry of the Gargano clade. Consistent with its early stratigraphic age, $D$. samniticus $\mathrm{sp}$. nov. bears a suite of primitive characters of the genus. Besides these, however, it also bears the autapomorphic relative proportion between $\mathrm{p} 3$ and $\mathrm{p} 4$.

The analysis of the erinaceids from Scontrone supports the assumption that Deinogalerix presumably descended from a hypothetical early - middle Miocene 'Parasorex-like' galericine. On the other hand, it seems to rule out the supposed common ancestry of the giant Deinogalerix and the small gymnure Apulogalerix from Gargano. Because the presumed ancestor of Deinogalerix dates back to the early - middle Miocene, the study corroborates the asynchronous colonization of the Apulia Platform.
\end{abstract}

Andrea Savorelli. Department of Earth Sciences, University of Florence, via La Pira 4, Florence 50121, Italy; andrea_savorelli@yahoo.it

Federico Masini. Department of Earth and Marine Sciences (DISTEM), University of Palermo, Via Archirafi 22, Palermo 90123, Italy; federico.masini@unipa.it

Paul P. A. Mazza. Department of Earth Sciences, University of Florence, via La Pira 4, Florence 50121, Italy; paul.mazza@unifi.it Maria Adelaide Rossi. Archaeological Superintendency of Abruzzo, via degli Agostiniani 14, Chieti 66100, Italy; mariaadelaide.rossi@beniculturali.it Silvano Agostini. Archaeological Superintendency of Abruzzo, via degli Agostiniani 14, Chieti 66100, Italy; silvano.agostini@beniculturali.it

http://zoobank.org/D8F74203-4822-422E-8CFF-4D339722145A

Savorelli, Andrea, Masini, Federico, Mazza, Paul P. A., Rossi, Maria Adelaide, and Agostini, Silvano. 2017. New species of Deinogalerix (Mammalia, Eulipotyphla) from the late Miocene of Scontrone (Abruzzo, central Italy). Palaeontologia Electronica 20.1.16A: $1-26$

palaeo-electronica.org/content/2017/1658-deinogalerix-from-scontrone 
Keywords: late Miocene; Abruzzo (central Italy); endemism; insular colonization; Deinogalerix; new species

\section{INTRODUCTION}

The 'terrible' erinaceid Deinogalerix Freudenthal, 1972, was first described over 40 years ago from the Gargano Promontory (Apulia, south-eastern Italy). It was found associated with a variety of large and small vertebrate taxa, with different degree of endemization, which now form the socalled 'Terre Rosse' faunal complex, otherwise known as the 'Mikrotia fauna' (Freudenthal, 1971; Masini et al., 2010). This faunal complex was largely found in the infillings of a set of karstic fissures. It includes an array of biochronologically ordered assemblages extended over an evolutionary time period (Freudenthal, 1976; De Giuli et al., 1987; Masini et al., 2013). The fissures are carved through Mesozoic limestones in the area included between Apricena and Poggio Imperiale, in the province of Foggia (Savorelli and Masini, 2016; Savorelli et al., 2016, with references therein). The limestones are actively quarried, exposing the fissures.

In the early 1990s remains of a fauna similar to that from Gargano and also containing Deinogalerix, but more ancient (see below) and less diversified, was found at Scontrone (Abruzzo, central Italy, Figure 1). The Scontrone and Gargano fossil records indicate the existence of a land, called the Apulia Platform, that has been repeatedly isolated from neighbouring mainland areas for long periods of time (Patacca et al., 2008a, 2008b, 2013). This land is an important natural laboratory for advancing our understanding of adaptation and evolutionary diversification of species in large islands (Freudenthal, 1971, 1976; De Giuli et al., 1987; Masini et al., 2010, 2013, and references within).

Deinogalerix is a multispecific genus. It was first described by Freudenthal (1972), based on an almost complete skeleton, which is the holotype of the largest species, Deinogalerix koenigswaldi Freudenthal, 1972. A few years later, Butler (1980) added four more species: $D$. brevirostris Butler, 1980, D. intermedius Butler, 1980, D. minor Butler, 1980 , and $D$. freudenthali Butler, 1980. In that paper, Butler proposed a phylogeny of the genus, grounded on Freudenthal's (1976) biochronology of the mammalian assemblages of Gargano, where the smallest species, $D$. freudenthali, is the com-

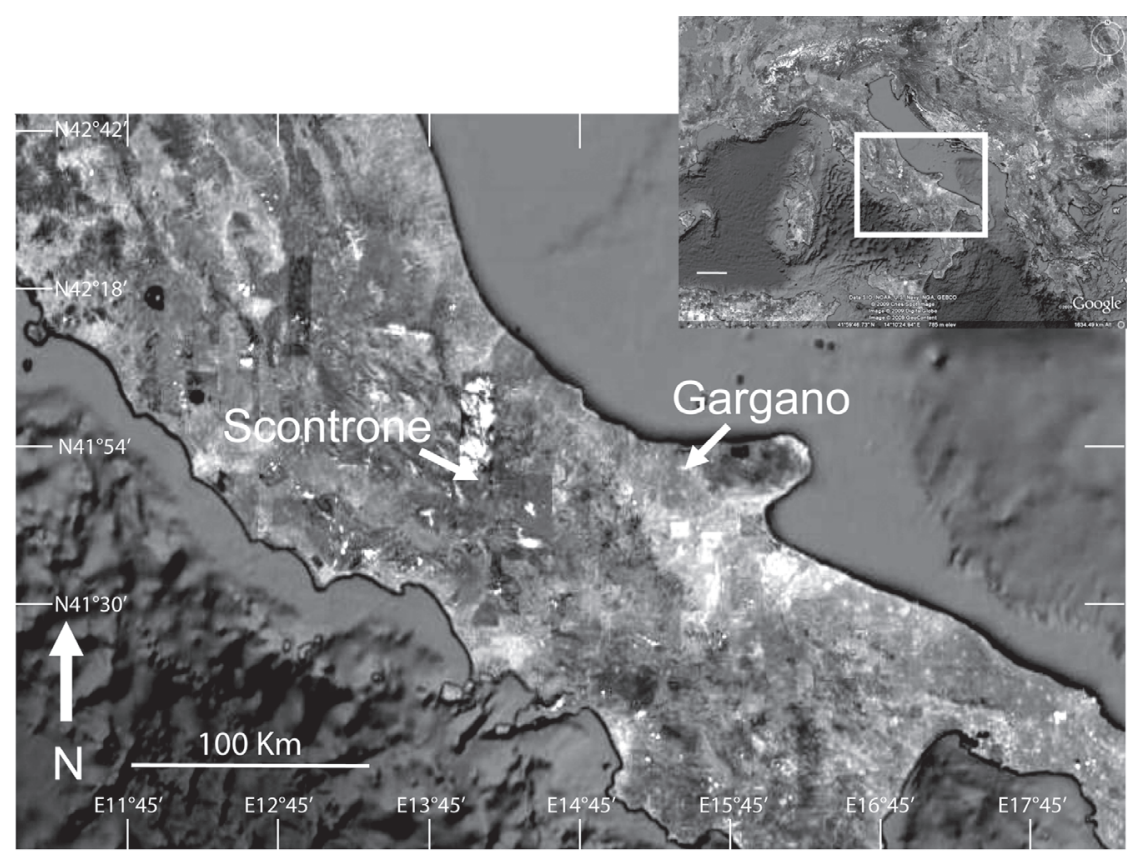

FIGURE 1. Location map of Scontrone and Gargano. From Mazza (2013a), modified. 
mon ancestor to all the other species. According to Butler (1980, p. 36), two lineages stem from $D$. freudenthali: one includes the larger-sized representatives and leads to the advanced $D$. koenigswaldi through the transitional $D$. intermedius; the second passes through $D$. minor and ends with $D$. brevirostris, which is coeval with, but smaller than, D. koenigswaldi. This scheme imposes an increase in size in both lineages, from the oldest to the most recent karstic fissure fillings.

Over forty years after Butler's (1980) monograph, Villier (2012) re-examined the taxonomy of the genus and downgraded Deinogalerix freudenthali and $D$. minor from species to morphotype rank, including them, together with a third koenigswaldi-morphotype, within the genus' type species Deinogalerix koenigswaldi. Villier et al. (2013) also introduced a new species, D. masinii, based on remains from the Gargano's most ancient fissure, M013 (Masini et al., 2013). Villier et al. (2013) remarked the morphological primitiveness of the new species, but excluded it from the direct ancestors of Butler's (1980) species. Villier et al. (2013, p. 74) reconsidered Villier's (2012) taxonomic revision and regarded the Gargano species of Deinogalerix described in Butler (1980) as a "...more modern [than $D$. masinii, note added by the present writers] group of Deinogalerix represented by $D$. koenigswaldi and $D$. freudenthali at the extreme." Later on, Villier and Carnevale (2013, p. 902) agreed with Villier et al. (2013) stating "[...] that only two former species [besides $D$. masinii, note added by the present writers] can be interpreted as valid: D. koenigswaldi, the largest, most derived, and most variable in size; and the smaller and less derived, D. freudenthali." Finally, Villier (2012) and Villier and Carnevale (2013) informed about a second, nearly complete skeleton of $D$. koenigswaldi from the fissure Mikrotia 010 at Cava dell'Erba (Gargano).

Butler (1980), van den Hoek Ostende (2001), and Ziegler (2005) worked on the genus' phylogenetic relationships, and McKenna et al. (1997) on its classification. All four of these studies agreed in including Deinogalerix in Galericini. Butler (1980) thought that it derived from a still unknown gymnure from Asia, which he assumed was the most likely source area for these erinaceids. Butler (1980), however, rejected that Deinogalerix could be closely related either to the galericines known at those times in Europe, or to Lanthanotherium Filhol, 1891, which he considered as a relative of modern moonrats of southern Asia. Van den Hoek Ostende (2001) assumed that Deinogalerix derived from a middle - late Miocene 'Parasorex-like' ancestor and showed that Deinogalerix clusters with Schizogalerix Engesser, 1980, and Parasorex von Meyer, 1865, the latter including $P$. socialis von Meyer, 1865, $P$. depereti (Crochet, 1986), and $P$. ibericus (Mein and Martín-Suárez, 1993). Ziegler (2005) stated that Deinogalerix is sister taxon to Schizogalerix and Parasorex. Villier in Villier et al. (2013), although sharing the opinion that Deinogalerix stemmed from Parasorex, argued for an earlier forerunner than that supposed by van den Hoek Ostende (2001).

Deinogalerix was first reported from Scontrone by Mazza and Rustioni (2008), based on the fragmental right maxillary SCT 232, with associated M3 and fragmental M2. The two authors attributed the specimen to $D$. freudenthali, because of its apparent morphological primitiveness, relatively small size, and old stratigraphic age.

Several issues on the taxonomy of Deinogalerix are still unsettled. Butler (1980, p. 36) distinguished the different species of Deinogalerix based primarily on size, with the addition of only few morphological features. He stressed that the specimens from fissures FH, G1 and San Giovannino range too widely in size to be included all in one species, and supposed the co-existence of two different entities. Villier and Carnevale (2013) simplified Butler's (1980) taxonomy, as explained above. We find Butler's (1980) opinions fairly convincing and share many of his considerations. Hence, we adopt a conservative option and provisionally deem his species legitimate. Deinogalerix from Scontrone is thus compared with the species introduced by Butler (1980) and Villier et al. (2013) and described here as $D$. samniticus sp. nov. and as Deinogalerix sp. Besides SCT 232, all the other remains of Deinogalerix that have been recovered from Scontrone over the last 20 years have never been analysed in detail. In this paper we present a formal taxonomic description of these erinaceids, together with a discussion on their relation within the other species of the genus. Piecing together all the available information, we also address the issues of the potential continental origin of the genus, as well as of its dispersal to the Apulia Platform.

\section{GEOLOGICAL SETTINGS AND ORIGIN OF THE FAUNA}

The Scontrone faunal remains come from tidal-flat aeolian calcarenites at the base of the Lithothamnion Limestone, a Miocene carbonate ramp widespread in the central-southern Apen- 


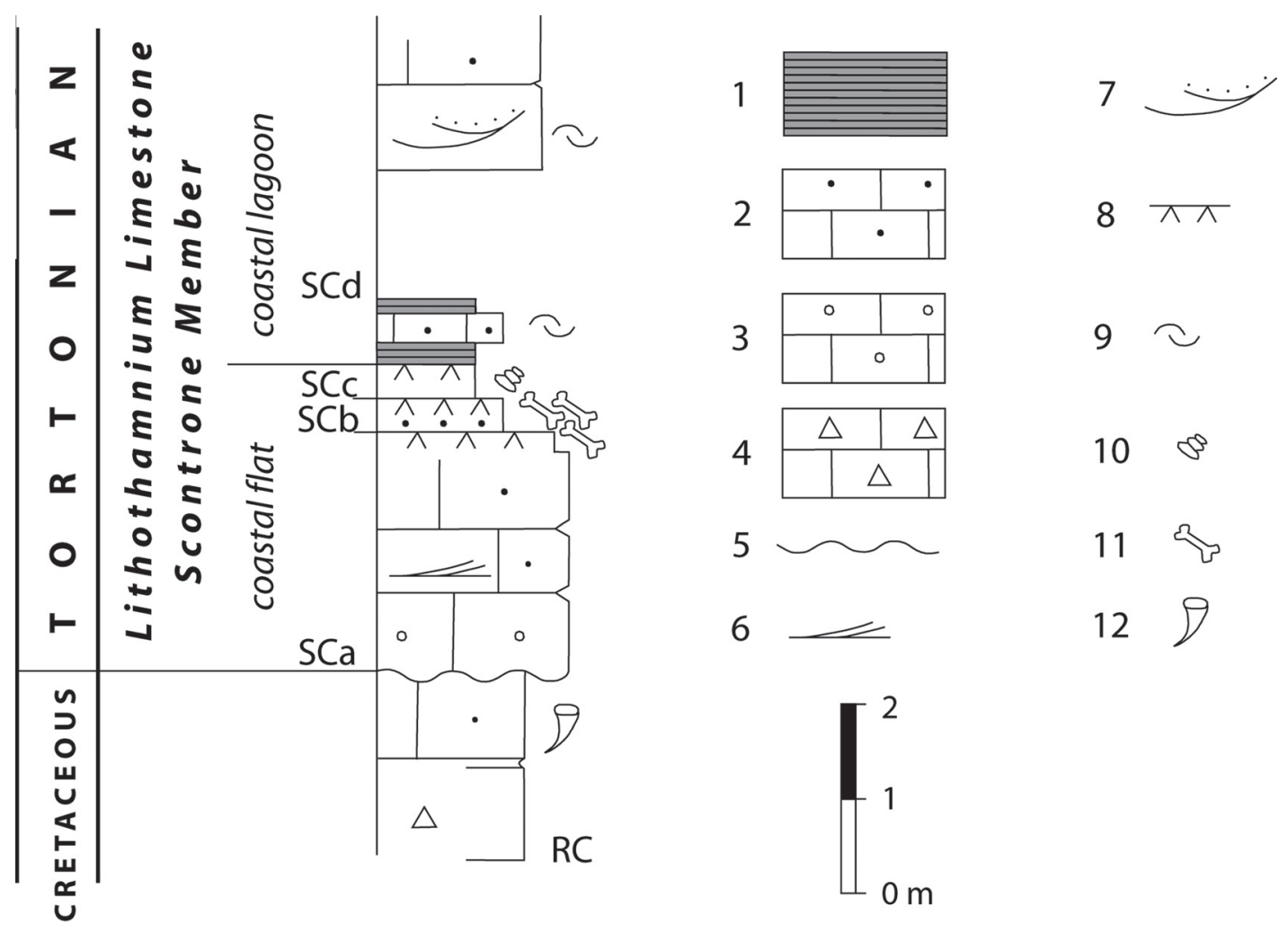

FIGURE 2. Schematic stratigraphy of the early Tortonian site of Scontrone (from Patacca et al., 2008a, modified). Succession showing the stratigraphic position of the bonebeds within the Scontrone Member of the Lithothamnium Limestone Formation. RC Rudist-bearing Calcarenite; SC Scontrone Member of the Lithothamnium Limestone Formation; SCa-SCd facies units of the Scontrone Member recording major shifts in the depositional setting and biotic associations ( $\mathrm{SCa}=$ costal bar deposits; SCb = tidal creek deposits; SCc = marsh deposits; SCd = lagoon deposits). 1-Calcareous marls; 2-Bioclastic calcarenites; 3-Bioclastic calcarenites with oversized well-rounded lithoclast lags; 4Lithoclastic calcirudites; 5-Major disconformity; 6-Low-angle cross-bedding; 7-Trough cross-bedding; 8-Root traces; 9-Oyster shell lags; 10-Hydrobiids; 11-Bonebeds; 12-Rudists. For further details see Patacca et al. (2008a).

nines. Based on its well-established stratigraphic location (Figure 2), the vertebrate bearing level is dated to about 9 m.y. (Patacca et al., 2013). In contrast, like for many other insular vertebrate assemblages from karstic fissure fillings, the age of the Gargano fauna is uncertain and hotly debated. It is notorious that fissure fillings can be exposed to reworking processes. Nonetheless, the Terre Rosse yielded a rich fossil record, quite coherent from the evolutionary viewpoint and from that of the composition of the assemblages. For this reason, reworking has been considered negligible (Masini et al., 2010). There is a general consensus that the fossiliferous fissure fillings are upper Miocene (Freudenthal et al., 2013; Masini et al., 2013; Savorelli et al., 2016), but unfortunately, the data available is of no aid in determining the exact chronology of the fauna within this time span. Over the years, the authors (e.g., Freudenthal, 1971; Agustí, 1986; De Giuli et al., 1987; Freudenthal and Martín-Suárez, 2010; Freudenthal et al., 2013; Savorelli et al., 2016) dated the Gargano fossils relying on biostratigraphic-biochronological methods, which use the stratigraphic range of the presumed continental ancestors of the endemic taxa to set chronological constraints on the history of the insular faunas and of the fossil-bearing fissure fillings. A drawback of this method is that the different scholars (e.g., Freudenthal et al., 2013; Masini et al., 2013; Savorelli and Masini, 2016; Savorelli et al., 2016) dispute the identity of the continental ancestors, which does not contribute to a clear understanding of the origin and modes of colonization of the insular fauna.

The Terre Rosse karst fissures are locally sealed by late lower Pliocene marine deposits (Valleri, 1984; Abbazzi et al., 1996; Pavia et al., 2010), which impose an upper chronological constraint to the Gargano fossil records. Establishing their earliest age is far more problematic. They 
were originally dated to a time older than the Serravallian by Freudenthal (1971) founded on the chronological attribution, erroneous at the time, of the marine deposits capping the karstic fissures.

The time of first arrival of the forerunners of the Gargano species has been variously dated as late Tortonian (Freudenthal et al., 2013), late Tortonian or early Messinian (Freudenthal and MartínSuárez, 2010), Messinian (Freudenthal, 1985), and Messinian or early Pliocene (De Giuli et al., 1987). Hence, based on present knowledge, and until new convincing evidence will be published, the Scontrone fauna is to be considered more ancient than the Gargano assemblages.

Still discussed is the origin of the ScontroneGargano fauna and, more specifically, the number of events that gave rise to the endemic assemblages (Masini et al., 2010). One model theorizes that the fauna reached the Apulia Platform with a single colonizing event, or through several events very close in time (Freudenthal, 1971, 1985; Freudenthal and Martín-Suárez, 2006, 2010; van den Hoek Ostende et al., 2009; Freudenthal et al., 2013). The alternative model corresponds to Masini et al.'s (2002) so-called 'polyphasic' hypothesis, which assumes that the fauna is a palimpsest built up over time through a set of diachronous bioevents, which involve multiple (vicariant and/or dispersalist) mechanisms (Butler 1980; De Giuli et al., 1987; Mazza et al., 1995, 2009; Abbazzi et al., 1996; Mazza and Rustioni, 1996, 2008; Masini et al., 2002, 2008, 2010, 2013; Rook et al., 2006). Freudenthal et al. (2013) sponsor the single dispersal model and propose a Mammal Neogene (MN) zone 11 time frame for the colonization of the insular domain. In their opinion, this time period is the most suitable based on the overlapping ranges of distribution of the possible ancestors of the Gargano taxa. Nonetheless, the site of Scontrone is older (Patacca et al., 2013) than the time of colonization proposed by Freudenthal et al. (2013).

Supporters of the polyphasic model suggested the asynchronous dispersal of the Apulia Platform's colonizers. The ancestor of Hoplitomeryx arrived supposedly during the late Oligocene - early Miocene (Mazza, 2013b), that of the puzzling cricetid Mystemys during the MN 1-9 interval (Savorelli and Masini, 2016), that of Apulogalerix during the MN 9-10 time span (Masini and Fanfani, 2013), that of Mikrotia during the MN 1113 time period (Tesakov, personal commun., 2016), and that of Apatodemus at the time of the MN 13 zone (Savorelli et al., 2016).

\section{MATERIAL AND METHODS}

\section{Material}

The material from Scontrone examined for this study consists of two fragmental right maxillaries (SCT 19, SCT 232), two fragments of horizontal rami of left hemimandibles (SCT 243, SCT 246), and a well preserved, isolated, left m1 (SCT 347). The specimens are stored at the Centro di Documentazione Paleontologica Hoplitomeryx, at Scontrone. The numerous remains of Deinogalerix found in Gargano over the past years and considered here, are now housed in the National Museum of Natural History (Naturalis) of Leiden (Netherland) and in the Italian Departments of Earth Sciences of the Universities of Turin (DSTT) and Florence (DSTF).

The Scontrone material was compared with original specimens from the collection of the DSTF and casts made by the staff of the Naturalis. The comparative material of Deinogalerix is reported in Table 1. The casts are stored in the laboratories of the Archaeological Superintendency of Abruzzo (ASA) in Chieti. The material from the collection of Florence (fissures F15, F21c, P81D, NBS, F1, F8, F9) is stored in the DSTF. Pending future detailed analyses of the latter specimens, most of the remains from fissure $\mathrm{F} 15$ are here referred to as $D$. freudenthali, based on direct observations of their sizes and morphologies by the authors, but also on preliminary indications by Villier (2012). The material from fissures F21c, P81D, NBS, F1, F8, and $\mathrm{F9}$, which is still not formally attributed taxonomically, has been also used for comparison purposes. These specimens permitted the formulation of the revised diagnosis of the genus included below.

Comparisons were also made with Deinogalerix masinii, from the fissure Mikrotia 013 (= M013), and D. koenigswaldi (PU100044), from the fissure Mikrotia 010, based on Villier (2012), Villier et al. (2013), and Villier and Carnevale (2013), where the extent of the morphological and size variability of these taxa is presented in detail. Fissures Mikrotia 013 and Mikrotia 010 are located at Cava dell'Erba, Gargano. The remains from these deposits are preserved at the DSTT.

Finally, comparisons were also made with uncatalogued specimens of Parasorex socialis and Galerix exilis from La Grive Saint Alban, but also of Apulogalerix from fissures F1 and F32 from Gargano. All these remains are preserved at the DSTF. 
TABLE 1. Comparative material used for the present study; $(h)=$ holotype; $(p)=$ paratype.

\begin{tabular}{|c|c|c|c|}
\hline Species & Deposit & Inventory & Description \\
\hline \multirow[t]{2}{*}{ D. minor } & Fina $\mathrm{H}$ & RGM 178184 (h) cast & fragmental right jaw with $\mathrm{p} 2-\mathrm{m} 3$ \\
\hline & Gervasio 1 & RGM $179174(p)$ cast & fragmental left jaw with p3-m3 \\
\hline \multirow[t]{2}{*}{ D. intermedius } & Nazario 4 & RGM 179063 (h) cast & fragmental left jaw with p3-m1 \\
\hline & Chiro $20 \mathrm{C}$ & RGM $177982(p)$ cast & fragmental right maxillary with P3-M2 \\
\hline \multirow[t]{3}{*}{ D. brevirostris } & SG & RGM 179134 (h) cast & $\begin{array}{l}\text { skull with right } \mathrm{P} 1 \text {, both } \mathrm{P} 2 \mathrm{~s}, \mathrm{P} 3 \mathrm{~s}, \mathrm{P} 4 \mathrm{~s}, \mathrm{M} 1 \mathrm{~s} \text {, right } \\
\mathrm{M} 2-\mathrm{M} 3\end{array}$ \\
\hline & SG & RGM $179237(p)$ cast & fragmental right premaxillary with $I 1,13$ \\
\hline & SG & RGM $179232(p)$ cast & fragmental left jaw with p3-m2 (broken m1) \\
\hline \multirow[t]{5}{*}{ D. koenigswaldi } & SG & RGM 177777 (h) cast & $\begin{array}{l}\text { skull with both I1s, I3s, Cs, P1s, P3s, P4s, M1s, } \\
\text { M2s, M3s and right P2 }\end{array}$ \\
\hline & SG & RGM 177778 (h) cast & fragmental left jaw with $\mathrm{p} 1-\mathrm{m} 3$ \\
\hline & SG & RGM 177779 (h) cast & fragmental right jaw with $\mathrm{p} 1-\mathrm{m} 3$ \\
\hline & SG & RGM 179194 cast & skull with right $\mathrm{C}, \mathrm{P} 1, \mathrm{P} 4$ both $\mathrm{P} 3 \mathrm{~s}$ \\
\hline & SG & RGM 179147 cast & fragmental right jaw with $\mathrm{p} 3-\mathrm{m} 3$ \\
\hline \multirow[t]{16}{*}{ D. freudenthali } & $\mathrm{F} 15$ & F15-015 & fragmental left jaw with p2-p4 \\
\hline & F15 & F15-016 & fragmental left jaw with m3 \\
\hline & F15 & F15-031 & isolated left p4 \\
\hline & $\mathrm{F} 15$ & F15-032 & isolated right $\mathrm{M} 1$ \\
\hline & F15 & F15-033 & isolated right $\mathrm{M} 2$ \\
\hline & F15 & F15-034 & isolated right $\mathrm{m} 3$ \\
\hline & $\mathrm{F} 15$ & F15-036 & isolated left M3 \\
\hline & F15 & F15-037 & isolated left M3 \\
\hline & $\mathrm{F} 15$ & F15-038 & fragmental left maxillary with P3-M2 \\
\hline & F15 & F15-039 & fragmental left jaw with $\mathrm{m} 1, \mathrm{~m} 3$ \\
\hline & $\mathrm{F} 15$ & F15-041 & isolated right $\mathrm{P} 4$ \\
\hline & F15 & F15-042 & fragmental right jaw without teeth \\
\hline & F15 & F15-043 & isolated right $\mathrm{m} 1$ \\
\hline & $\mathrm{F} 15$ & F15-044 & isolated right m2 \\
\hline & F15 & F15-045 & isolated right $\mathrm{m} 2$ \\
\hline & F15 & F15-046 & isolated right p3 \\
\hline
\end{tabular}

\section{Methods}

Upper teeth are indicated with capital letters (e.g., M1, M2, M3), lower ones with lower case letters (e.g., m1, m2, m3). Figure 3 depicts the tooth nomenclature used in this paper. In the upper molars, the mesial cuspule between protocone and paracone, which is sometimes reported as paraconule in the literature, is here called protoconule following Engesser (1980). Moreover, the distal arm of metacone is indicated as metastylar crest (metastylar spur in Gould, 1995). We introduce in this paper the name postparacristid for the disto-lingual prologment of the paracone in p4$\mathrm{m} 1-3$.
Measurements were performed using a Mitutoyo Dial Calipers and are expressed in millimetres. Size measurements are reported in Table 2. Length ( $L$ ) and width (W) of the upper and lower teeth from Scontrone and of the specimens preserved in the DSTF have been measured following Prieto et al. (2010). In the lower teeth and in P3 and P4, W corresponds to Prieto et al.'s (2010) W2. In the third upper molar, $L$ is the minimum length from the mesial border to the distal angle of the crown (L2 in Prieto et al., 2010; LmM3 in Masini and Fanfani, 2013). The measurements of the specimens kept in Naturalis and DSTT collections were drawn from Butler (1980), Villier (2012), and 
TABLE 1 (continued).

\begin{tabular}{|c|c|c|c|}
\hline Species & Deposit & Inventory & Description \\
\hline \multirow[t]{2}{*}{ Deinogalerix sp. } & F21c & F21-001 & isolated left M1 \\
\hline & F21c & F21-002 & isolated right $\mathrm{p} 4$ \\
\hline \multirow[t]{11}{*}{ Deinogalerix sp. } & P81D & P81D-001 & fragmental left jaw without teeth \\
\hline & P81D & P81D-002 & fragmental left jaw without teeth \\
\hline & P81D & P81D-003 & fragmental right jaw without teeth \\
\hline & P81D & P81D-004 & fragmental left jaw with m2-m3 \\
\hline & P81D & P81D-009 & isolated left $\mathrm{m} 1$ \\
\hline & P81D & P81D-023 & left jaw with $\mathrm{p} 3$ \\
\hline & P81D & P81D-024 & left jaw with p3-p4 \\
\hline & P81D & P81D-025 & fragmental right maxillary with $\mathrm{P} 4$ \\
\hline & P81D & P81D-026 & isolated left P3 \\
\hline & P81D & P81D-027 & isolated left p3 \\
\hline & P81D & P81D-028 & isolated right $\mathrm{p} 4$ \\
\hline Deinogalerix sp. & NBS & NBS-001 & isolated left p4 \\
\hline \multirow[t]{3}{*}{ Deinogalerix sp. } & $\mathrm{F} 1$ & F1-006 & isolated left P4 \\
\hline & $\mathrm{F} 1$ & F1-007 & isolated left P4 \\
\hline & $\mathrm{F} 1$ & F1-009 & isolated left m2 \\
\hline Deinogalerix sp. & F8 & F8-040 & left jaw with c, p3-m3 (broken m1) \\
\hline \multirow[t]{4}{*}{ Deinogalerix sp. } & F9 & F9-014 & $\begin{array}{l}\text { fragmental skull with left } \mathrm{C} \text {, both } \mathrm{P} 1 \mathrm{~s}, \mathrm{P} 3 \mathrm{~s}, \mathrm{P} 4 \mathrm{~s}, \mathrm{M} 2 \mathrm{~s} \\
\text { and } \mathrm{M} 3 \mathrm{~s}\end{array}$ \\
\hline & F9 & F9-017 & fragmental left maxillary with $\mathrm{P} 1-\mathrm{P} 2, \mathrm{P} 4$ \\
\hline & F9 & F9-018 & isolated left M1 \\
\hline & F9 & F9-022 & fragmental right jaw with $\mathrm{p} 4$ \\
\hline
\end{tabular}

Villier et al. (2013). Butler (1980) did not report the analytical data of the remains of Deinogalerix koenigswaldi. The latter were therefore obtained from Villier (2012).

A Wild Heerbrugg microscope type 308700 was used for the morphological analyses. Photographs were taken with a Canon Powershot S70 and with a Panasonic Lumix DMC-TZ20 digital cameras, both mounted on a stand.

As explained in the introduction, we primarily adopted Butler's (1980) size-discrimination to distinguish the different species of Deinogalerix. Because the largest and smallest of Butler's (1980) species (i.e., $D$. freudenthali and $D$. koenigswaldi, respectively) are also the easiest to distinguish morphologically, they have been used as reference species for the differential diagnosis of the present paper. D. samniticus sp. nov. is also compared there with the most recently and very welldescribed species D. masinii (Villier et al., 2013).

\section{SYSTEMATIC PALAEONTOLOGY}

Class MAMMALIA Linnaeus, 1758

Superorder INSECTIVORA sensu Novacek, 1986 Order EULIPOTYPHLA Waddell, Okada, and Hasegawa, 1999

Family ERINACEIDAE Fischer, 1814

Subfamily GALERICINAE Pomel, 1848

Tribe GALERICINI Pomel, 1848

Genus DEINOGALERIX Freudenthal, 1972

Type Species. Deinogalerix koenigswaldi Freudenthal, 1972 from the Messinian (latest Miocene) of Gargano (Apulia, south-eastern Italy), fissure San Giovannino (Foggia, south-eastern Italy; Freudenthal, 1972).

Included Species. Deinogalerix brevirostris Butler, 1980; Deinogalerix freudenthali Butler, 1980; Deinogalerix intermedius Butler, 1980; Deinogalerix minor Butler, 1980; Deinogalerix masinii Villier et al., 2013; Deinogalerix samniticus sp. nov. 


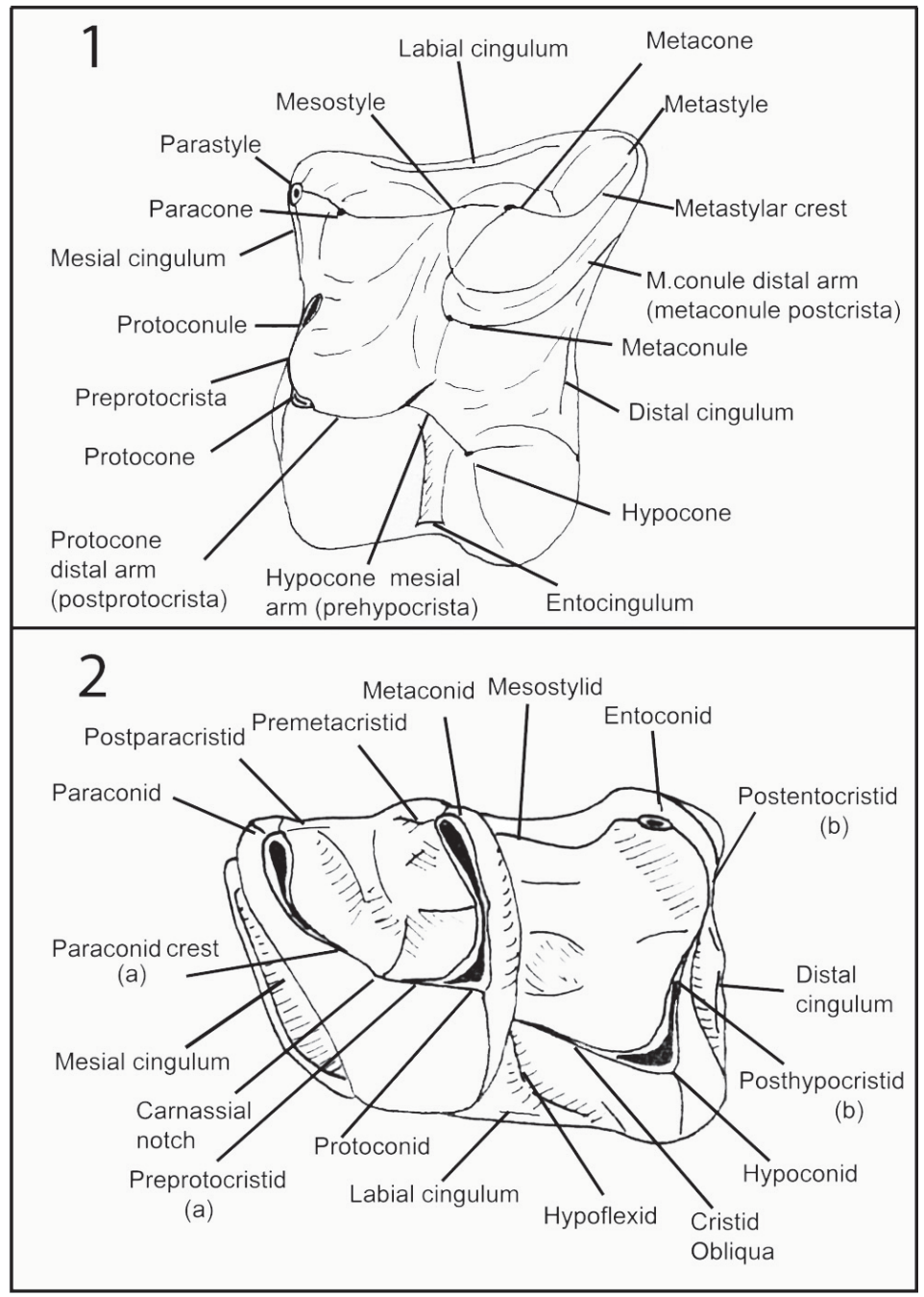

FIGURE 3. Guide to dental morphology terms used in this paper, drawn from Engesser (1980), Gould (1995), Lopatin (2006) by Masini and Fanfani (2013), and slightly modified here. 1, Upper molar. 2, Lower molar; (a) paralophid (paracristid) $=$ paraconid crest + preprotocristid sensu Lopatin (2006); (b) postcristid (hypolophid) $=$ postentocristid + posthypocristid sensu Lopatin (2006).

Distribution. Early Tortonian (early late Miocene) of Scontrone (Abruzzo, central Italy) to Messinian (late late Miocene) of Gargano (south-eastern Italy).

Original diagnosis. See Freudenthal (1972).

Emended Diagnosis (from Villier et al., 2013, p. 65). 'Large galericini; I1 much larger than I2 and I3; P3, P4, p3, p4, and the trigonid of $\mathrm{m} 1$ enlarged; posterior molars reduced; $\mathrm{P} 3$ and p4 bunodont; on p4 the trigonid is well-defined, the paralophid is absent or partially developed and the metaconid and the distal-ridge form a continuum via a bulbous metacristid; hypocone and protostyle on P3 invariably present; hypoconule present on P4; connection protocone-metaconule usually absent on M1 and $\mathrm{M} 2$; on $\mathrm{M} 1$ and $\mathrm{M} 2$ the postcrista of the metaconule reaches the bucco-distal corner of the tooth, distal cingulum bipartitionated; mesostyle of $\mathrm{M} 1$ and M2 round and not divided; metastylar crest of M3 well-developed and inflated; mandible with small coronoid process and low condyle; supraorbital processes present and formed by the frontal'.

Revised Diagnosis. Large galericini; 11 much larger than I2 and I3; P3, P4, p3, p4, and trigonid of $\mathrm{m} 1$ enlarged; posterior molars reduced; $\mathrm{P} 3$ and $\mathrm{p} 4$ bunodont; p4 with well-delineated trigonid, weak mesial part of paracristid, preprotocristid blunt, metaconid and distal cingulum joined by bulbous mesostylid; hypocone constantly present in P3; protocone and metaconule usually not connected in $\mathrm{M} 1$ and $\mathrm{M} 2$; in M1-2 distal cingulum interrupted, or distal arm of metaconule sometimes confluent 
TABLE 2. Odontometrics of Deinogalerix samniticus sp. nov. and Deinogalerix sp. (SCT243). Measurement: L: length; W: width, Lm: minimum length (only M3), aL: alveolar length, $H(m 1, p 2)$ : height of mandible below $\mathrm{m} 1$ and $\mathrm{p} 2, \mathrm{~W} \mathrm{~m} 1$ : width of the mandible below $\mathrm{m} 1$. Italics: inferred value.

\begin{tabular}{|c|c|c|c|c|c|c|c|c|c|c|}
\hline & \multicolumn{10}{|c|}{ Dental Measurements } \\
\hline & $\mathbf{L}$ & $\mathbf{W}$ & $\mathbf{L}$ & $\mathbf{W}$ & $\mathbf{L}$ & $\mathbf{W}$ & $\mathbf{L}$ & $\mathbf{W}$ & $\mathbf{L}$ & $\mathbf{w}$ \\
\hline & \multicolumn{2}{|c|}{ p3 } & \multicolumn{2}{|c|}{ p4 } & \multicolumn{2}{|c|}{ m1 } & \multicolumn{2}{|c|}{ m2 } & \multicolumn{2}{|c|}{ m3 } \\
\hline SCT246 & 8.8 & 5.0 & 12.1 & 7.6 & 12.25 & 1 & 6.5 & 1 & 5.8 & 1 \\
\hline SCT243 & 7.1 & 3.5 & 10 & 6.7 & 10.3 & 6.5 & & & & \\
\hline \multirow[t]{3}{*}{ SCT347 } & & & & & 12.1 & 8 & & & & \\
\hline & $\mathbf{L}$ & $\mathbf{W}$ & $\mathbf{L}$ & $\mathbf{W}$ & $\mathbf{L}$ & $\mathbf{W}$ & $\mathbf{L}$ & $\mathbf{W}$ & Lm & $\mathbf{W}$ \\
\hline & \multicolumn{2}{|c|}{ P3 } & \multicolumn{2}{|c|}{ P4 } & \multicolumn{2}{|c|}{ M1 } & \multicolumn{2}{|c|}{ M2 } & \multicolumn{2}{|c|}{ M3 } \\
\hline SCT19 & 10.3 & 8.9 & 1 & 10.9 & & & & & & \\
\hline \multirow[t]{4}{*}{ SCT232 } & & & & & & & & & 5.85 & 6.3 \\
\hline & \multicolumn{10}{|c|}{ Mandible Measurements } \\
\hline & $a L$ & $\mathrm{aL}$ & $a L$ & $a L$ & $\mathrm{H}$ m1 & W m1 & $\mathrm{H} \mathrm{p} 2$ & & & \\
\hline & m1-m3 & p2-p4 & p4-p3 & p4-p3 & & & & & & \\
\hline SCT246 & 27.55 & 32.7 & 21.1 & 20.6 & 18.5 & 14.5 & $>15$ & & & \\
\hline
\end{tabular}

with uninterrupted distal cingulum (Figure 4.1-2); bulging and undivided mesostyle in M1 and M2; metastylar crest of M3 well-developed and inflated; supraorbital processes present and formed by frontal bone; mandible with small coronoid process, low condyle, and mental foramen under mesial root or between roots of $\mathrm{p} 3$.

\section{Deinogalerix samniticus sp. nov.} Figure 5, Figure 6

\section{zoobank.org/50CCEB68-BD93-4783-B342-293716175377}

Diagnosis. Medium-sized Deinogalerix with proportionally very small p3 and large p4, p4 as long as $\mathrm{m} 1$. Trigonid of $\mathrm{m} 1$ broad, with mesiolingual bulge (Figure 4.3-4) dipping downward and protruding lingually. M3 with well-developed parastyle. Strong and continuous mesiolabial cingulum in $\mathrm{m} 2$. P3 narrow, with relatively small protocone. In p4 paraconid imperfectly defined and trigonid valley closed lingually (Figure 4.5-6).

Differential Diagnosis. Deinogalerix samniticus sp. nov. differs from all the other species of Deinogalerix by having proportionally a smaller $\mathrm{p} 3$ and a larger p4. Compared to D. koenigswaldi, D. samniticus sp. nov. has smaller overall size; smaller p3, $\mathrm{m} 1$, and $\mathrm{m} 2$; cheek teeth lower-crowned, imperfectly divided protocone-hypocone in P3 (Figure 4.7-8); lower protocone in P4; more acute anterolabial corner in M3; lingually-closed trigonid basin and less-defined paraconid in $\mathrm{p} 4 ; \mathrm{m} 1$ with broad, trigonid not concave lingually, and with mesiolingual bulge dipping downward and protruding lin- gually; strong and continuous mesiolabial cingulum in $\mathrm{m} 2$; labially-prominent hypoconid in $\mathrm{m} 3$.

Deinogalerix samniticus sp. nov. differs from $D$. freudenthali by being larger sized, but also by possessing: larger $\mathrm{p} 4$ and $\mathrm{m} 1$; slightly more bunodont teeth; M3 with faint protoconule and more developed parastyle; trigonid of $\mathrm{m} 1$ with slightly lower lingual enamel wall and mesiolingual bulge dipping downward and protruding lingually; m2 with longer mesiolabial cingulum.

Deinogalerix samniticus sp. nov. differs from D. masinii by having: larger teeth (especially p4 and $\mathrm{m} 1$ ); smaller protocone, imperfectly divided protocone-hypocone and not well defined parastyle in P3; faint protoconule and more developed parastyle in M3; stronger and longer mesiolabial cingulum in $\mathrm{m} 2$.

Etymology. After the Samnites, an Italic people living in Samnium, the ancient region where Scontrone is located. Because the genus Deinogalerix is masculine (Zijlstra and Flynn, 2015), the species name is treated here as masculine.

Synonymy. 2008, Deinogalerix freudenthali, Mazza and Rustioni, p. 209, figure 6. 2013, Deinogalerix freudenthali, Villier et al., p. 64.

Material. Holotype: SCT 246, fragment of horizontal ramus of left hemimandible, still partly embedded in rock, preserving p3, p4, alveoli of p2, and most of the molar row, except $\mathrm{m} 1$, which is largely broken (Figure 5.1-2, Figure 6). Paratypes: fragmental right maxillaries SCT 232, with M3 and postero-lingual portion of M2 (Figure 5.8), and SCT 19, 


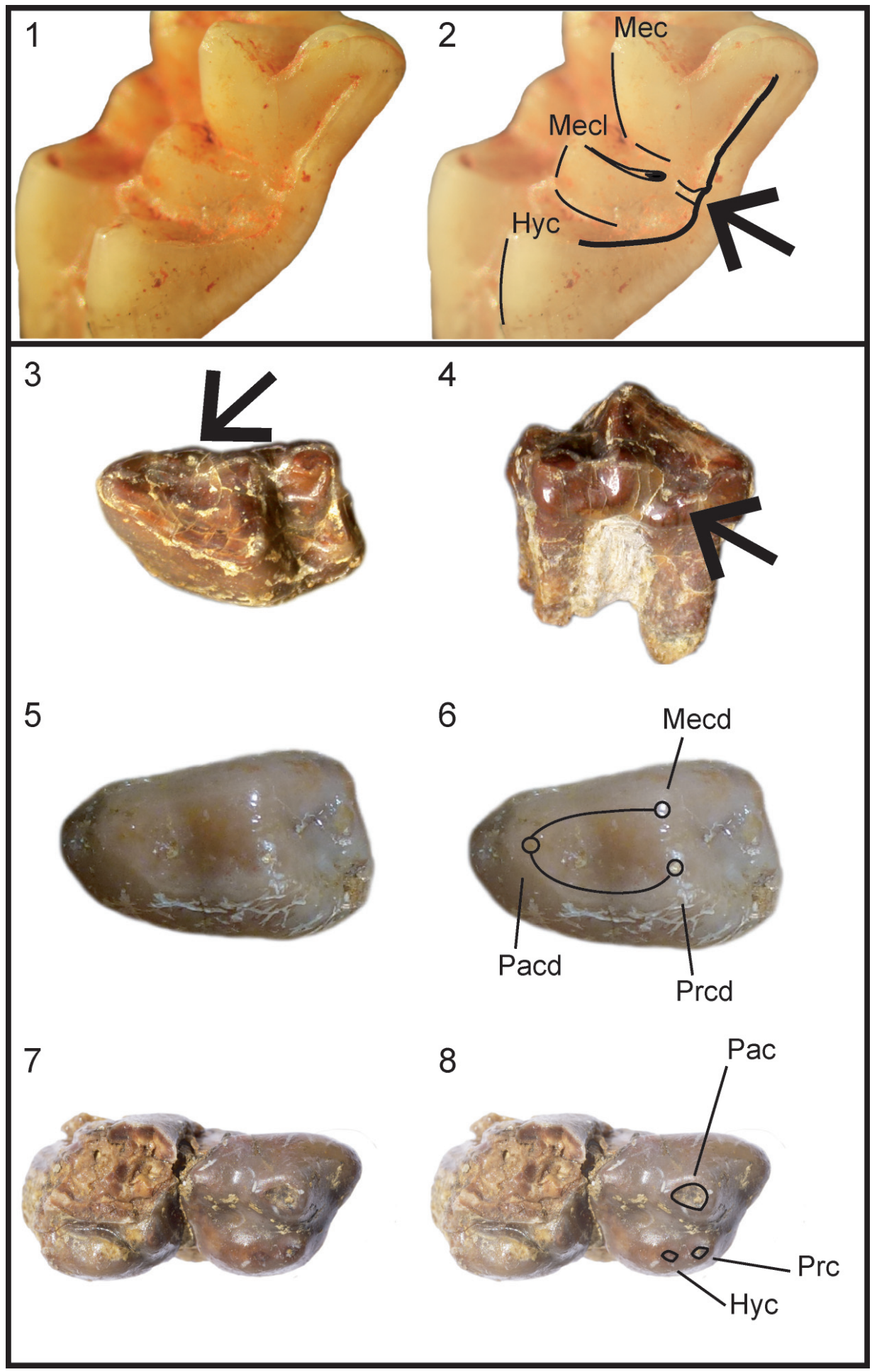

FIGURE 4. 1, Left M1 (F9-018), undetermined Deinogalerix sp. from fissure F9, oblique, occluso-distal view. 2, same as 1 with sketch showing contact of the distal arm of the metaconule with the uninterrupted distal cingulum. 3, left $\mathrm{m} 1$ (paratype SCT 347), Deinogalerix samniticus sp. nov., occlusal view. 4, same specimen as 3, lingual view. Arrows in 3 and 4 showing mesiolingual bulge. 5, left p4 (holotype SCT 246), Deinogalerix samniticus sp. nov., occlusal view. 6, same as 5, with sketch showing roundish, delimited lingually, trigonid valley. 7, right P3-P4 (paratype SCT 19), Deinogalerix samniticus sp. nov., occlusal view. 8, same as 7 with sketch showing the weak separation of protocone and hypocone. Hyc $=$ Hypocone, Mecl = Metaconule, $\mathrm{Mec}=$ Metacone, Mecd = Metaconid, Pac $=$ Paracone, Pacd $=$ Paraconid, Prc $=$ Protocone, Prcd $=$ Protoconid. Figures not to scale . 

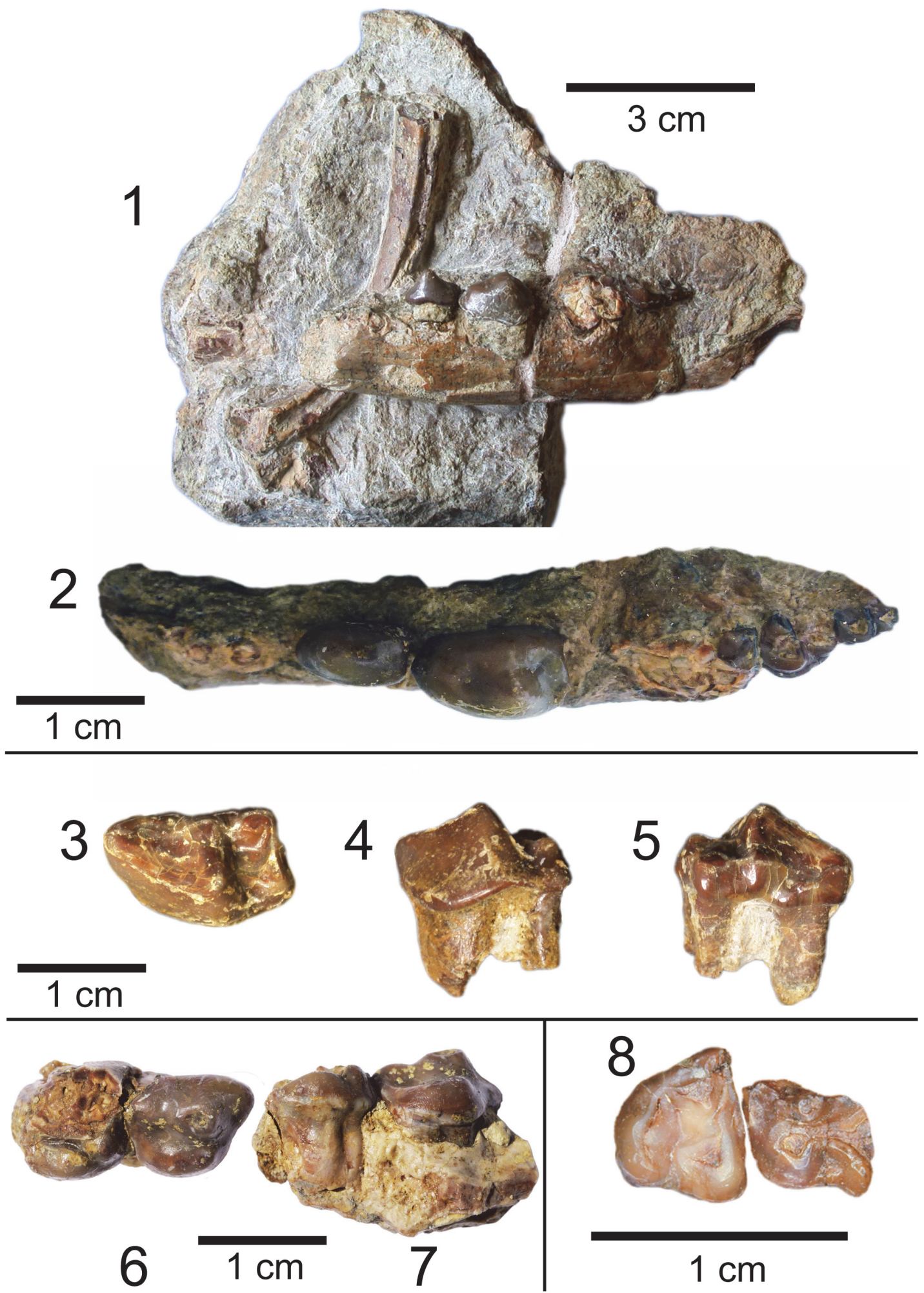

FIGURE 5. Deinogalerix samniticus sp. nov., from Scontrone. 1-2, Holotype, fragment of left hemimandible, with $\mathrm{p3}$, $\mathrm{p} 4$, alveoli of $\mathrm{p} 2$, broken $\mathrm{m} 1, \mathrm{~m} 2$, and $\mathrm{m} 3$ partially embedded in the rock (SCT 246). 1, labial view; 2, occlusal view. 35, Paratype, isolated left $\mathrm{m} 1$ (SCT 347). 3, occlusal view; 4, labial view; 5, lingual view. 6-7, Paratype, fragmental right maxillary with complete P3 and fragmented P4 (SCT 19). 6, occlusal view; 7, lingual view. 8, Paratype, fragmental right maxillary, with M3 and postero-lingual portion of M2 (SCT 232). 

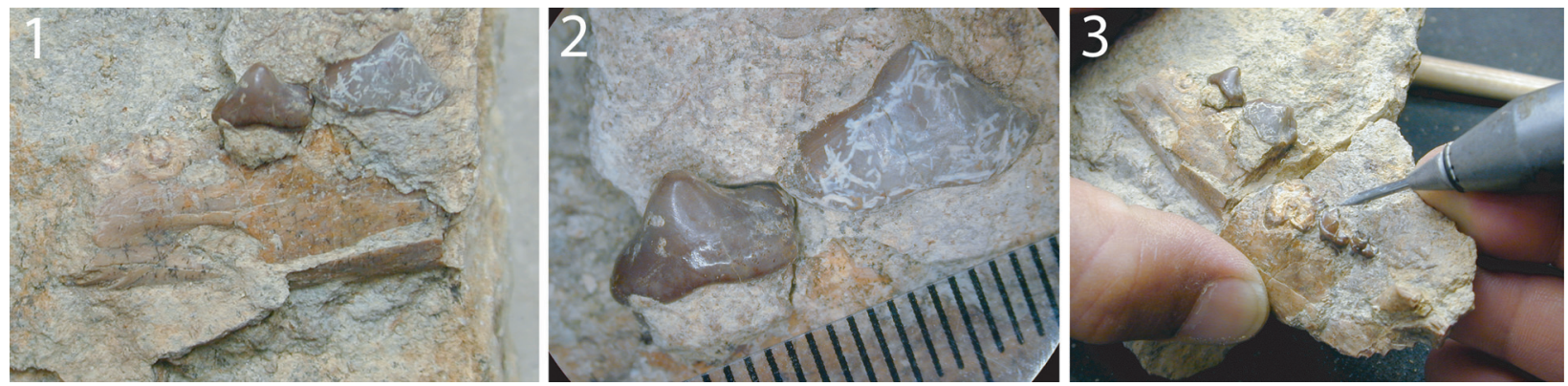

FIGURE 6. 1-3, Holotype SCT 246 during its preparation from the rock matrix by vibrotool. The figure shows the premolars still partially encased in the rock matrix.

with complete P3 and fragmented P4; left m1 SCT 347.

Type Locality. Outskirts of Scontrone, southern border of the National Park of Abruzzi, L'Aquila, central Italy $\left(41^{\circ} 45^{\prime} 15.54^{\prime \prime} \mathrm{N}, 14^{\circ} 2^{\prime} 13.14^{\prime \prime} \mathrm{E}\right)$.

Horizon. Scontrone Member, Lithothamnion Limestone.

Age. Lower Tortonian (lower upper Miocene) (Patacca et al., 2008b).

Measurements. See Table 2.

Description SCT 246 (Figure 5.1-2). Fragment of horizontal ramus of left hemimandible still partly embedded in rock. Specimen broken in front of $\mathrm{p} 2$ alveoli and aborally to $\mathrm{m} 3$, but still preserving $\mathrm{p} 3$, p4, alveoli of p2, and most of the molar row, except $\mathrm{m} 1$, whose dental crown is largely broken. Mesial root of p2 slightly smaller than distal one. Tooth presumably somewhat smaller than p3 based on relative proportion of roots. In ventral view (specimen not observable in medial view) distal end of mandibular symphisis extended to mesial root of p3. Mental foramen located under mesial root of p3 and elongated mesially by groove. Horizontal ramus particularly thick latero-medially under molar section.

p3. Unworn, blunt, fairly low-crowned, dominated by protoconid triangular and symmetrical in side view. Metaconid absent. Labially, protoconid relatively swollen at the base. Two roots apparently straight and not divergent mesio-distally from one another. In occlusal view crown with sub-oval outline and with talonid represented by blunt and small cuspule, prominent disto-lingually. p3 narrower and markedly smaller than p4 (Table 2) and separated from alveoli of $\mathrm{p} 2$ by short diastema.

p4. Moderately worn, large, and massive, quite more massive and larger than p3. Occlusal profile sub-oval, slightly wider distally, distal margin of tooth straight and transverse labio-lingually to horizontal ramus. Crown formed mesially by three fairly low and blunt cuspids, i.e., paraconid, protoconid, and metaconid. Protoconid dominant, metaconid somewhat lower than protoconid. Cleft between protoconid and metaconid clearly visible distally. Paraconid robust and low mesially. Protoconid connected with paraconid by blunt and low paralophid. Trigonid valley roundish, very shallow, and delimited lingually by very blunt and robust mesial border of metaconid (premetacristid?) and postparacristid. Distal side of crown slightly concave, distal cingulum very inclined labially and bearing small cuspule disto-lingually. Metaconid with bulbous disto-lingual mesostylid fused with cingulum.

m1-m3. Molars in typical fashion of Deinogalerix. Crown of $\mathrm{m} 1$ almost completely broken, with only entoconid, mesio-labial part of cingulum, and general outline of crown preserved. $\mathrm{m} 2$ and $\mathrm{m} 3$ largely visible, except entoconid of $\mathrm{m} 2$ and part of lingual enamel wall and of entoconid of $\mathrm{m} 3$, still embedded in rock. $\mathrm{m} 1$ largest tooth (approximately same length as $\mathrm{p} 4$ ) with very elongated trigonid. $\mathrm{m} 2$ and $\mathrm{m} 3$ quite worn. $\mathrm{m} 2$ much smaller and with shorter trigonid than $\mathrm{m} 1, \mathrm{~m} 3$ slightly shorter, but quite more slender than $\mathrm{m} 2 . \mathrm{m} 2$ with strong continuous mesial and labial cingulum prolonged distally to base of hypoconid. $\mathrm{m} 3$ with relatively narrower talonid than $\mathrm{m} 2$, hypoconid prominent labially, robust mesial cingulum, small labial cingulum at hypoflexid, from which issues very small enamel pillar.

Specimen SCT 347 (Figure 5.3-5). Two-rooted left $\mathrm{m} 1$, well preserved, but rather worn. Marked disproportion between trigonid and talonid, typical of Deinogalerix. Trigonid with dominant, high and continuous, blade-like paralophid, formed by fusion of paraconid crest and preprotocristid, carnassial notch lacking. Lingual wall of trigonid high. Mesial part of lingual enamel wall between paraconid and metaconid (i.e., postparacristid) slightly protruding lingually forming a mesiolingual bulge (Figure 4.3- 
4) and dipping downwards towards collar. Upper margin of lingual enamel profile indented by wear at distal end of postparacristid. Metaconid and protoconid transversally aligned in occlusal view. Talonid narrower and much lower than trigonid. Hypoconid low and connected mesially with protoconid by cristid obliqua and lingually with entoconid by postcristid. Entoconid slightly higher than hypoconid. Hypoconulid absent. Presence of faint labial cingulum. Weak and short distal cingulum, not connected with postentocristid. Enamel much thinner in trigonid than in talonid. Mesial root much larger than distal root.

Specimen SCT 19 (Figure 5.6-7). Fragmental right maxillary with complete P3 and fragmented P4.

P3. Bulbous tooth with typical Deinogalerix morphology. Trapezoidal outline, with labio-distal margin slightly inclined lingually. Crown very low and blunt, dominated by large and high paracone, placed in labial position. Shallow depression separating paracone from small, distally prominent metastyle (metacone of Villier and Carnevale, 2013). Tooth elongated mesially by shouldershaped parastyle. Lingual side of tooth formed by protocone-hypocone complex. Small protocone and large hypocone, separated by very shallow depression, which is rapidly obliterated by wear (Figure 4.7-8). Based on wear pattern, protocone apparently slightly higher than hypocone. Hypocone bulbous, elongated and declining gently towards distal margin of crown, where it prolongs in cingular fashion. Lingual root with faint furrow not extended to lingual enamel wall, which appears complete.

P4. Only mesio-lingual half of tooth preserved. Larger than P3, with small mesio-lingual protocone. Differs from P3 by having shallow notch between protocone and crest-like hypoconal structure. Notch opens in valley between paracone and lingual cusps. Evident groove in lingual root, which corresponds to separation between protoconehypocone.

Specimen SCT 232 (Figure 5.8). Fragmental right maxillary, with $\mathrm{M} 3$ and postero-lingual portion of M2.

M2. Hypocone only cusp preserved. Mesial arm of hypocone connected with distal arm of protocone, distal arm of hypocone lacking. Metaconule partially preserved and well developed, placed in more mesial position than hypocone. Fragment of distal arm of metaconule apparently still preserved. Short entocingulum in valley between hypocone and pro- tocone. Protocone and metaconule separated. Enamel thick.

M3. Sub-triangular outline. Mesial margin almost straight, disto-labial margin markedly arched, lingual margin slightly concave. Tooth somewhat broader than long. Protocone larger than all other cusps of tooth, and prolonged labially in narrow preprotocrista, which bears very reduced protoconule extended towards antero-lingual corner. Paracone connected with well-developed parastyle. Parastyle projected mesiolabially and labial margin of paracone slightly concave. Angle between mesial and labial margins of crown acute. Metacone strongly shifted to disto-lingual position, disto-labial part of tooth with distal arm of paracone and metacone joined to form continuous and arched crest, ending in inflated metastylar crest, separated from distal arm of protocone. Trigon valley deep and opened lingually. Very short entocingulum at outlet of the trigon valley. Short mesial cingulum. Protocone with flat wear surface. Enamel thick.

Comparison. The specimens from Scontrone have the typical characters of the genus: very large size, enlarged P3, P4, p3, p4, and trigonid of $\mathrm{m} 1$, very reduced $\mathrm{m} 2$ and $\mathrm{m} 3$, bunodont $\mathrm{P} 3$ and $\mathrm{p} 4$, well-developed metastylar crest in M3. Nonetheless, a number of differences exclude these teeth from those of all the known species. In particular Deinogalerix samniticus sp. nov. has a set of unusual dental proportions. Its middle-sized mandible bears a proportionally very large p4 (as large as those of $D$. intermedius and $D$. koenigswaldi), smaller p3 (in the size ranges of $D$. freudenthali, $D$. minor, and $D$. brevirostris), and large $\mathrm{m} 1$ and $\mathrm{M} 3$ (see Figure 7, Figure 8, Table 3, Table 4, Table 5).

Morphologically, the occlusal outline of $p 3$ is somewhat less stretched disto-lingually than in the other species. The crown of p3 is lower than in $D$. koenigswaldi (RGM 179147, 177778, 177779) and than in the specimens of Deinogalerix sp. from fissures $\mathrm{F} 8$ and P81D.

In $\mathrm{p} 4$, the difference in height between the protoconid-metaconid complex and the paraconid is similar to that visible in the p4s of Deinogalerix freudenthali from F15 and D. masinii; it is somewhat lesser in the p4s of the other species of Deinogalerix. The paraconid is also less well-identified than in other species, but it is connected with the metaconid and protoconid, similarly to $D$. freudenthali from $\mathrm{F} 15$. In contrast, the paraconid tends to be more isolated in all the other species $(D$. masinii included). In labial view, the profile of the distal face of the protoconid is less steep than in $D$. 


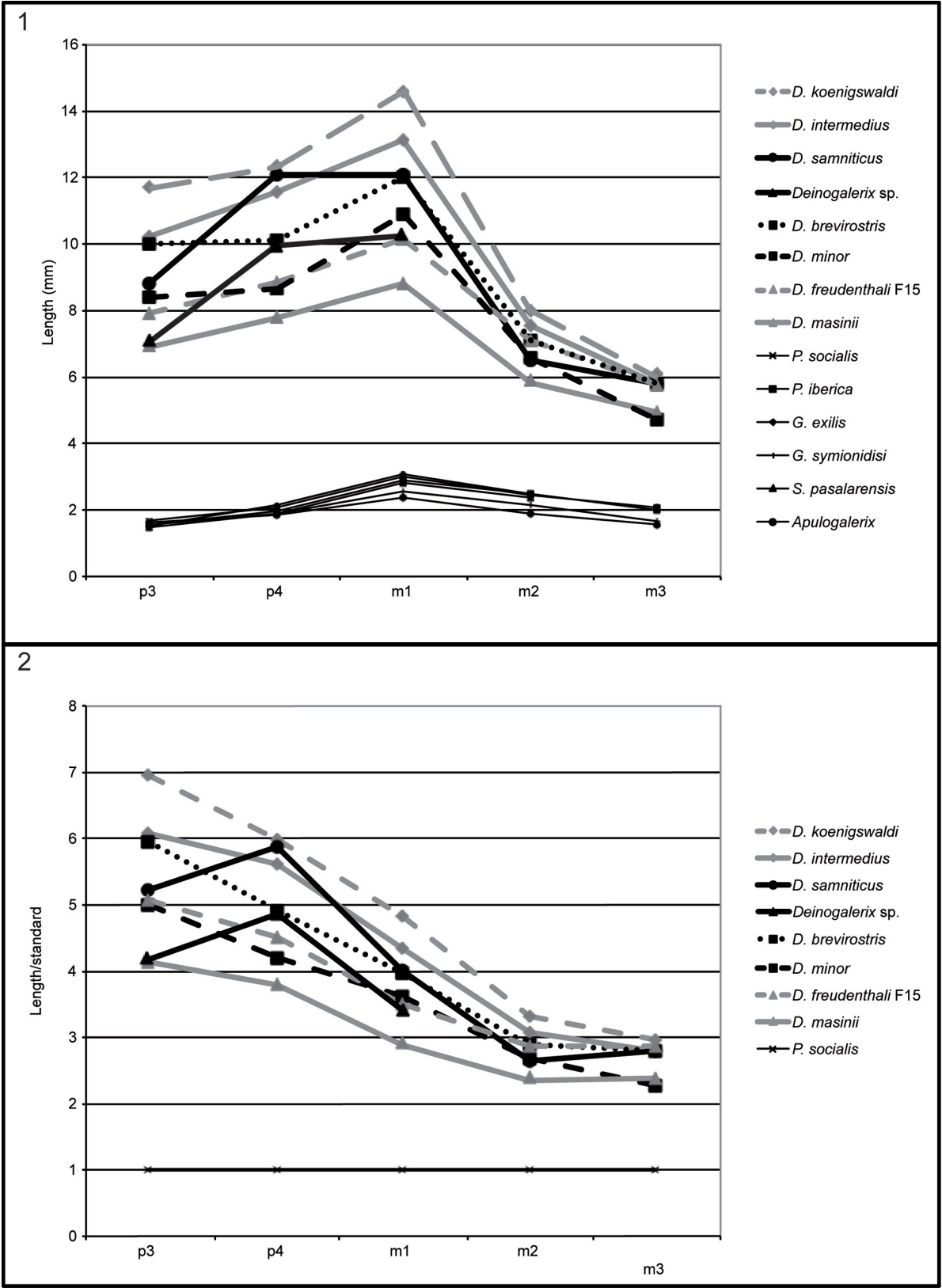

FIGURE 7. Comparisons of p3-m3 lengths in the different species of Deinogalerix, as well as in Parasorex, Galerix, Schizogalerix, and Apulogalerix (measurements and abbreviations in Table 3). 1, The graph shows that in Apulogalerix, Parasorex and other continental galericines molars grow progressively larger towards $\mathrm{m} 1$, which is the largest tooth of the row. The fourth lower premolar is larger than p3, which, in contrast, is the smallest of the toothrow (it is somewhat smaller than m3). Compared to the mainland counterparts, Deinogalerix bears a very large $\mathrm{m} 1$ (due to the increase of the trigonid length) and larger premolars, that grow progressively smaller moving rostrally, but less than in the continental genera (p3 intermediate in size between $\mathrm{m} 1$ and $\mathrm{m} 2$ ). The Scontrone specimen shows the size increase from $\mathrm{m} 3$ to $\mathrm{m} 1$ typical of Deinogalerix. In contrast, it bears a very large $\mathrm{p} 4$, similar in size to $\mathrm{m} 1$ and in the dimensional ranges of $D$. koenigswaldi, and a very reduced p3, more similar to those of the smaller and more primitive species of Deinogalerix from Gargano. 2, Ratio diagram comparing the p3-m3 lengths (see Table 4) in Deinogalerix samniticus sp. nov. with other species of Deinogalerix, using Parasorex socialis from La Grive as the standard (horizontal line). All the Deinogalerix specimens show a similar trend where the proportions of $\mathrm{m} 2$ and $\mathrm{m} 3$ are parallel to the standard, whereas, starting from $\mathrm{m} 1$, the teeth proportionally increase in size respect to the standard. It is noteworthy that this trend reaches its maximum expression in D. koenigswaldi. Compared to the other species of Deinogalerix, the curve of $D$. samniticus sp. nov., shows a steeper rise toward $\mathrm{p} 4$, and it is the only one that drops toward p3. 


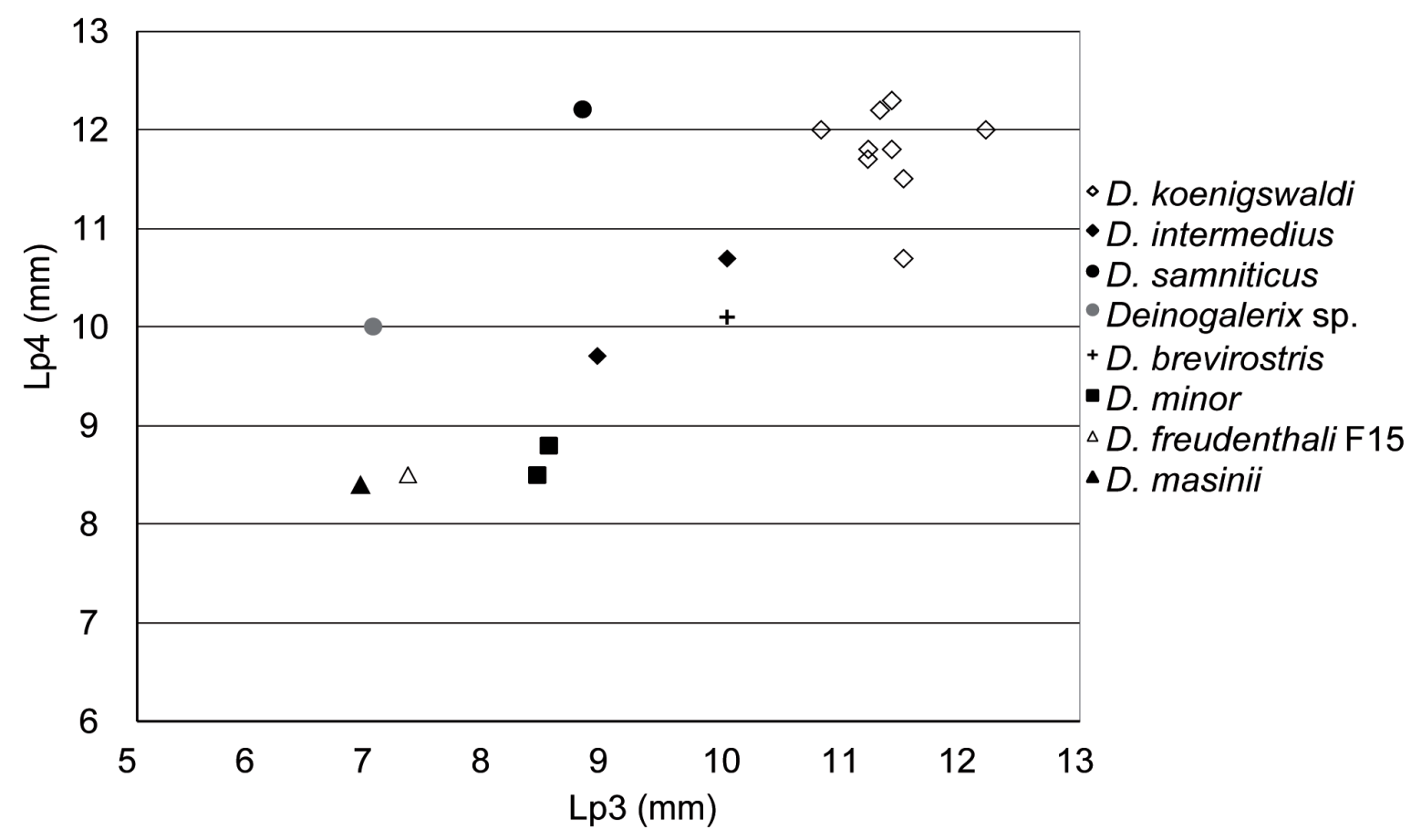

FIGURE 8. Scatter plot of Lp4 vs Lp3 (values in Table 5) for the species of Deinogalerix. The Deinogalerix specimens from Gargano align roughly in a linear trend. D. samniticus sp. nov. and Deinogalerix sp., in contrast, display an anomalously short p3. It is worth noting that also the smaller and more primitive species, e.g., D. freudenthali from F15 and D. masinii from M013, have fairly short p3s. Measurements in $\mathrm{mm}$.

koenigswaldi and closer to $D$. freudenthali from F15.

The lingual side of the $\mathrm{m} 1$ of Deinogalerix samniticus sp. nov. is characterized by the downward dip of the enamel margin of the mesiolingual bulge, which causes an unusual wear pattern. In all the other species but Deinogalerix masinii, this enamel profile is continuous and straight. In $D$. masinii the mesiolingual bulge never dips downward and ligually as much as in D. samniticus (Villier, personal commun., 2015). Because of the mesiolingual bulging, in occlusal view the trigonid of $\mathrm{m} 1$ of $D$. saminiticus appears somewhat broader than those of the m1s of most of the other species, which in contrast have an outline more concave lingually. Without detailed descriptions of this feature at hand, inspection of Villier et al.'s (2013) figure 3 suggests that also the $\mathrm{m} 1$ of $D$. masinii has a broad trigonid. $\mathrm{m} 1$ is relatively lower-crowned than in the more advanced species (e.g., D. koenigswaldi). In $D$. samniticus sp. nov. the talonid is proportionally longer than in $D$. koenigswaldi. It does not present a mesial and labial cingulum at the base of the trigonid, as in the other species except $D$. masinii.
The $\mathrm{m} 2$ of Deinogalerix samniticus sp. nov. has a strong and continuous mesio-labial cingulum that extends distally to the base of the hypoconid. A similar, but shorter cingulum is possessed by all the small species of Deinogalerix (i.e., $D$. freudenthali and $D$. masinii). This cingulum is generally weaker and discontinuous, and only sporadically uninterrupted (i.e., PU 100044: Villier and Carnevale, 2013) in D. koenigswaldi.

The m3 of Deinogalerix samniticus sp. nov. is bounded by a stronger cingulum than in the other species. In $D$. koenigswaldi this cingulum is virtually absent. m3 of $D$. samniticus sp. nov. has a hypoconid prominent labially, similar to that of $D$. freudenthali and $D$. masinii. In contrast, $D$. minor and $D$. koenigswaldi have a less prominent hypoconid, which gives the tooth a more rounded distolabial outline.

$\mathrm{P} 3$ is lower-crowned than in the other species. It is proportionally somewhat narrower than in $D$. masinii and $D$. koenigswaldi. The protocone is very small. It falls, dimensionally, at the lower end of the size ranges of the genus. RGM 177982 (paratype of $D$. intermedius) and a specimen from fissure Pirro 81/D (P81/D-026) possess P3s with proto- 
TABLE 3. Basic statistic parameters of lengths in mm of lower teeth (p3-m3) of the different Deinogalerix species, as well as in Parasorex, Galerix, Schizogalerix, and Apulogalerix. The mean values of Apulogalerix are actually grand means (i.e., mean of the means) of six different populations. The ranges have been approximated to the decimal digit to make them comparable to those reported by Butler (1980) and Doukas (1986). $N=$ number of specimens; $\bar{x}=$ mean values; $\sigma=$ standard deviations. * Inferred from diagrams and figures. Raw data for Figure 7.1.

\begin{tabular}{|c|c|c|c|c|c|c|c|c|c|c|}
\hline \multirow{3}{*}{$\begin{array}{l}\text { Genus Species } \\
\text { Deinogalerix }\end{array}$} & \multirow{3}{*}{ Locality } & \multirow{3}{*}{ Source } & \multicolumn{8}{|c|}{ Length } \\
\hline & & & \multicolumn{4}{|c|}{ p3 } & \multicolumn{4}{|c|}{ p4 } \\
\hline & & & $\mathrm{N}$ & $\bar{x}$ & $\sigma$ & range & $\mathrm{N}$ & $\bar{x}$ & $\sigma$ & range \\
\hline D. masinii & M013 & Villier, 2012; Villier et al., 2013 & 6 & 6.97 & 0.225 & $6.6-7.2$ & 5 & 7.82 & 0.559 & $6.9-8.4$ \\
\hline D. freudenthali & F15 & This paper & 2 & 7.90 & 0.849 & $7.3-8.5$ & 2 & 8.85 & 0.495 & $8.5-9.2$ \\
\hline D. minor & $\begin{array}{l}\text { Various } \\
\text { fissures }\end{array}$ & Butler, 1980 & 3 & 8.40 & 0.100 & $8.3-8.5$ & 2 & 8.65 & 0.212 & $8.5-8.8$ \\
\hline D. brevirostris & SG Low & Butler, 1980 & 1 & 10.00 & l & 1 & 1 & 10.10 & l & l \\
\hline D. samniticus & Scontrone & This paper & 1 & 8.80 & l & I & 1 & 12.10 & I & I \\
\hline Deinogalerix sp. & Scontrone & This paper & 1 & 7.10 & l & l & 1 & 10.00 & l & l \\
\hline D. intermedius & $\begin{array}{l}\text { Various } \\
\text { fissures }\end{array}$ & Butler, 1980 & 6 & 10.23 & 0.728 & $8.9-11$ & 7 & 11.56 & 1.108 & $9.7-12.6$ \\
\hline D. koenigswaldi & $\begin{array}{l}\text { SG, SG } \\
\text { Low }\end{array}$ & Butler, 1980 & 6 & 11.70 & 0.360 & $11.3-12$ & 7 & 12.34 & 0.560 & $11.5-13$ \\
\hline \multicolumn{11}{|l|}{ Galerix } \\
\hline G. symeonidisi & Aliveri & Doukas, 1986 & 3 & 1.56 & & $1.5-1.6$ & 14 & 1.90 & & $1.7-2.1$ \\
\hline G. exilis & Goldberg & Ziegler, 1983 & 123 & 1.55 & 0.095 & $1.3-1.8$ & 100 & 2.08 & 0.098 & $1.9-2.4$ \\
\hline \multicolumn{11}{|l|}{ Parasorex } \\
\hline P. socialis & La Grive & Masini \& Fanfani, 2013 & 15 & 1.68 & 0.137 & $1.5-1.9$ & 39 & 2.06 & 0.088 & $1.9-2.3$ \\
\hline P. ibericus & Otura 1 & Mein \& Martin Suarez, 1993 & 2 & 1.56 & & $1.5-1.6$ & 3 & 1.96 & & $1.9-2$ \\
\hline \multicolumn{11}{|l|}{ Schizogalerix } \\
\hline S. pasalarensis & Pasalar & Engesser, $1980\left(^{*}\right)$ & 1 & 1.48 & I & I & 7 & 1.88 & 0.040 & $1.8-1.9$ \\
\hline Apulogalerix & All fissures & this paper & 6 & 1.64 & & $1.6-1.7$ & 6 & 1.85 & & $1.8-1.9$ \\
\hline
\end{tabular}

cones of approximately the same size, whereas $D$. masinii has P3s with the proportionally largest protocones of the genus. Accessory cusps that are sporadically present in the P3s of other species are absent in SCT 19. D. samniticus sp. nov. differs from $D$. masinii by having an imperfectly defined parastyle.

P4 bears a low protocone, like in Deinogalerix masinii and $D$. freudenthali from $\mathrm{F} 15$. In contrast, $D$. brevirostris, $D$. intermedius, and $D$. koenigswaldi have a quite higher protocone. The hypocone is comparatively as high as it is in smaller species, and quite lower than those of $D$. brevirostris, $D$. intermedius, and $D$. koenigswaldi. It is not split. In the other species the hypocone can be either complete, or variably split. It is quite more split in $D$. koenigswaldi. The tooth bears no accessory cusps.
In M3 of Deinogalerix samniticus sp. nov. the parastyle is somewhat more developed than in the other species, giving the labial wall a slightly concave profile. The parastyle is projected mesio-labially as in the small species $D$. masinii and $D$. freudenthali from F15 and not mesially as in $D$. koenigswaldi and the F9 specimens. Moreover, the angle between the mesial and labial margins is acute in $D$. samniticus sp. nov., $D$. freudenthali from $\mathrm{F} 15$, and $D$. masinii, and more open in $D$. brevirostris, $D$. koenigswaldi, and in a still undetermined species, Deinogalerix sp. from F9.

\section{Deinogalerix sp. \\ Figure 9}

Material. Left hemimandible SCT 243. 
TABLE 3 (continued).

\begin{tabular}{|c|c|c|c|c|c|c|c|c|c|c|c|c|}
\hline \multirow[b]{2}{*}{ Genus Species } & \multicolumn{12}{|c|}{ Length } \\
\hline & \multicolumn{4}{|c|}{$\mathrm{m} 1$} & \multicolumn{4}{|c|}{ m2 } & \multicolumn{4}{|c|}{ m3 } \\
\hline Deinogalerix & $\mathrm{N}$ & $\bar{x}$ & $\sigma$ & range & $\mathrm{N}$ & $\bar{x}$ & $\sigma$ & range & $\mathrm{N}$ & $\bar{x}$ & $\sigma$ & range \\
\hline D. masinii & 9 & 8.77 & 0.308 & $8.3-9.2$ & 10 & 5.88 & 0.467 & $5.3-6.5$ & 5 & 4.86 & 0.363 & $4.1-5.5$ \\
\hline D. freudenthali & 2 & 10.14 & 0.325 & $9.9-10.4$ & 2 & 7.10 & 0.566 & $6.7-7.5$ & 3 & 5.77 & 0.221 & $5.5-5.9$ \\
\hline D. minor & 2 & 10.90 & 0.141 & $10.8-11$ & 3 & 6.57 & 0.208 & $6.4-6.8$ & 1 & 4.70 & 1 & I \\
\hline D. brevirostris & 1 & 12.00 & l & I & 2 & 7.05 & 0.071 & $7-7.1$ & 1 & 5.80 & I & I \\
\hline D. samniticus & 2 & 12.18 & 0.106 & $12.1-12.25$ & 1 & 6.50 & I & l & 1 & 5.80 & I & I \\
\hline Deinogalerix sp. & 1 & 10.30 & l & I & & & & & & & & \\
\hline D. intermedius & 7 & 13.13 & 0.916 & $12-14.5$ & 6 & 7.53 & 0.344 & $7.1-8$ & 2 & 5.80 & 0.000 & $5.8-5.8$ \\
\hline D. koenigswaldi & 7 & 14.57 & 0.650 & $13.5-15.3$ & 7 & 8.14 & 0.480 & $7.6-9$ & 5 & 6.16 & 0.470 & $5.8-6.9$ \\
\hline \multicolumn{13}{|l|}{ Galerix } \\
\hline G. symeonidisi & 2 & 2.55 & & $2.5-2.6$ & 8 & 2.14 & & $2-2.3$ & 4 & 1.65 & & $1.5-1.8$ \\
\hline G. exilis & 150 & 3.07 & 0.077 & 2.8-3.4 & 150 & 2.49 & 0.100 & $2.4-2.8$ & 150 & 2.11 & 0.093 & $1.7-2.3$ \\
\hline \multicolumn{13}{|l|}{ Parasorex } \\
\hline P. socialis & 49 & 3.02 & 0.082 & $2.9-3.2$ & 72 & 2.46 & 0.063 & $2.2-2.6$ & 40 & 2.08 & 0.100 & $1.9-2.3$ \\
\hline P. ibericus & 5 & 2.90 & & $2.9-3$ & 2 & 2.47 & & $2.4-2.5$ & 3 & 2.01 & & $2-2.1$ \\
\hline \multicolumn{13}{|l|}{ Schizogalerix } \\
\hline S. pasalarensis & 3 & 2.80 & 0.098 & $2.7-2.9$ & 2 & 2.39 & 0.021 & $2.4-2.4$ & & & & \\
\hline Apulogalerix & 6 & 2.39 & & $2.3-2.5$ & 6 & 1.91 & & $1.8-2$ & 6 & 1.57 & & $1.5-1.7$ \\
\hline
\end{tabular}

Type Locality. Outskirts of Scontrone, southern border of the National Park of Abruzzi, L'Aquila, central Italy $\left(41^{\circ} 45^{\prime} 15.54^{\prime \prime} \mathrm{N}, 14^{\circ} 2^{\prime} 13.14^{\prime \prime} \mathrm{E}\right)$.

Horizon. Scontrone Member, Lithothamnion Limestone.

Age. Lower Tortonian (lower upper Miocene) (Patacca et al., 2008b).

Measurements. See Table 2.

Description Specimen SCT 243 (Figure 9.1-2). Still partly embedded in rock. Specimen broken in front of mesial root of p3 and at level of m2. p3, basal parts of $\mathrm{p} 4$ and $\mathrm{m} 1$, and mesial part of $\mathrm{m} 2$ still preserved. Part of both roots of $p 2$ visible. $p 2$ presumably somewhat smaller than $\mathrm{p} 3$ based on relative proportion of the roots. Specimen cut by fracture between p3 and p4 that displaces rostral portion of horizontal ramus ventrally. Mental foramen under mesial border of distal root of p3 and elongated mesially by groove. Horizontal ramus quite high and thick under molar section and tapering rostrally.

p3. Slightly worn, blunt, fairly low-crowned, dominated by protoconid triangular and symmetrical in side view. Metaconid absent. Labially, protoconid with relatively swollen base. Two roots straight and divergent mesio-distally from one another. In occlusal view crown slender mesio-distally with subtriangular outline and talonid extended distally and with blunt and small cuspule, prominent disto-lingually. p3 narrower and markedly smaller than p4 (Table 2 ) and separated from alveoli of p2 by short diastema.

p4. Crown badly damaged, only lingual and mesiolabial part of enamel wall preserved. Tooth large and massive, much more than p3. Occlusal outline sub-triangular, slightly wider distally, distal margin of tooth straight but obliquely inclined disto-labially. m1. General outline of crown and mesio-labial part of cingulum preserved. $\mathrm{m} 1$ largest tooth (approxi- 
TABLE 4. Ratios of lower teeth length (p3-m3) in Deinogalerix samniticus sp. nov. with other species of Deinogalerix respect to the standard (Parasorex socialis from La Grive). Raw data for Figure 7.2.

\begin{tabular}{|c|c|c|c|c|c|c|}
\hline \multirow{2}{*}{$\begin{array}{c}\text { Genus } \\
\text { Species }\end{array}$} & \multirow[b]{2}{*}{ Locality } & \multicolumn{5}{|c|}{ Length ratio } \\
\hline & & p3 & $\mathrm{p} 4$ & m1 & m2 & m3 \\
\hline \multicolumn{7}{|l|}{ Deinogalerix } \\
\hline D. masinii & Fissure M013 & 4.14 & 3.80 & 2.91 & 2.39 & 2.34 \\
\hline D. freudenthali & Fissure F15 & 5.08 & 4.52 & 3.50 & 2.87 & 2.87 \\
\hline D. minor & Various fissures & 4.99 & 4.20 & 3.61 & 2.68 & 2.26 \\
\hline D. brevirostris & Fissure SG Low & 5.94 & 4.91 & 3.98 & 2.87 & 2.79 \\
\hline $\begin{array}{l}\text { D. samniticus sp. } \\
\text { nov. SCT } 246\end{array}$ & Scontrone & 5.23 & 5.88 & 4.04 & 2.65 & 2.79 \\
\hline Deinogalerix sp. & Scontrone & 4.22 & 4.86 & 3.41 & & \\
\hline D. intermedius & Various fissures & 6.08 & 5.61 & 4.35 & 3.07 & 2.79 \\
\hline D. koenigswaldi & Fissures SG and SG Low & 6.95 & 5.99 & 4.83 & 3.32 & 2.97 \\
\hline \multicolumn{7}{|l|}{ Parasorex } \\
\hline P. socialis & La Grive & 1.00 & 1.00 & 1.00 & 1.00 & 1.00 \\
\hline
\end{tabular}

TABLE 5. Lengths of p3 and p4 of single specimens of Deinogalerix. Raw data for Figure 8.

\begin{tabular}{|c|c|c|c|c|c|}
\hline Species & Locality & Specimen & Source & Lp3 & Lp4 \\
\hline D. masinii & Fissure M013 & PU128502 & Villier et al., 2013 & 6.9 & 8.4 \\
\hline D. freudenthali & Fissure F15 & F15-015 & This paper & 7.3 & 8.5 \\
\hline \multirow[t]{2}{*}{ D. minor } & Fissure Fina $\mathrm{H}$ & RGM178184 & Butler, 1980 & 8.5 & 8.8 \\
\hline & Fissure Gervasio & RGM179174 & Butler, 1980 & 8.4 & 8.5 \\
\hline \multirow[t]{2}{*}{ D. intermedius } & Fissure Nazario 4 & RGM179063 & Butler, 1980 & 10.0 & 10.7 \\
\hline & WG 354294 & RGM178085/086 & Butler, 1980 & 8.9 & 9.7 \\
\hline D. brevirostris & Fissure SG Low & RGM179232 & Butler, 1980 & 10.0 & 10.1 \\
\hline \multirow[t]{9}{*}{ D. koenigswaldi } & Fissure SG & RGM177778 & Villier, 2012 & 11.3 & 12.2 \\
\hline & Fissure SG & RGM177779 & Villier, 2012 & 11.2 & 11.8 \\
\hline & Fissure SG & RGM179145 & Villier, 2012 & 10.8 & 12.0 \\
\hline & Fissure SG & RGM179147 & Villier, 2012 & 11.4 & 12.3 \\
\hline & Fissure SG & RGM179148 & Villier, 2012 & 12.2 & 12.0 \\
\hline & Fissure SG & RGM179149 & Villier, 2012 & 11.4 & 11.8 \\
\hline & Fissure SG & RGM179193 & Villier, 2012 & 11.5 & 10.7 \\
\hline & Fissure SG Low & RGM179206 & Villier, 2012 & 11.2 & 11.7 \\
\hline & Fissure SG Low & RGM179224 & Villier, 2012 & 11.5 & 11.5 \\
\hline \multirow[t]{2}{*}{ D. samniticus sp. nov. } & Scontrone & SCT 246 & This paper & 8.8 & 12.1 \\
\hline & Scontrone & SCT 243 & This paper & 7.1 & 10.0 \\
\hline
\end{tabular}

mately same length as $\mathrm{p} 4)$ with very elongated trigonid. Mesial part of lingual enamel wall between paraconid and metaconid, i.e., postparacristid, slightly concave lingually and with no mesiolingual bulge.

m2. Undescribable fragment.

Comparison. SCT 243 shares with Deinogalerix samniticus sp. nov. the relative proportions of $\mathrm{p} 3$, $\mathrm{p} 4$, and $\mathrm{m} 1$. It differs from it by its smaller overall size, and by having a rostrally tapering horizontal ramus. p3 is more slender and not roundish as in D. samniticus sp. nov., and $\mathrm{p} 4$ has an oblique and not transverse distal edge. The trigonid of $\mathrm{m} 1$ is uniformly concave lingually without any trace of mesiolingual bulge.

SCT 243 has $p 3$ as large as that of $D$. masinii, $\mathrm{p} 4$ the same size as that of $D$. brevirostris, and $\mathrm{m} 1$ 

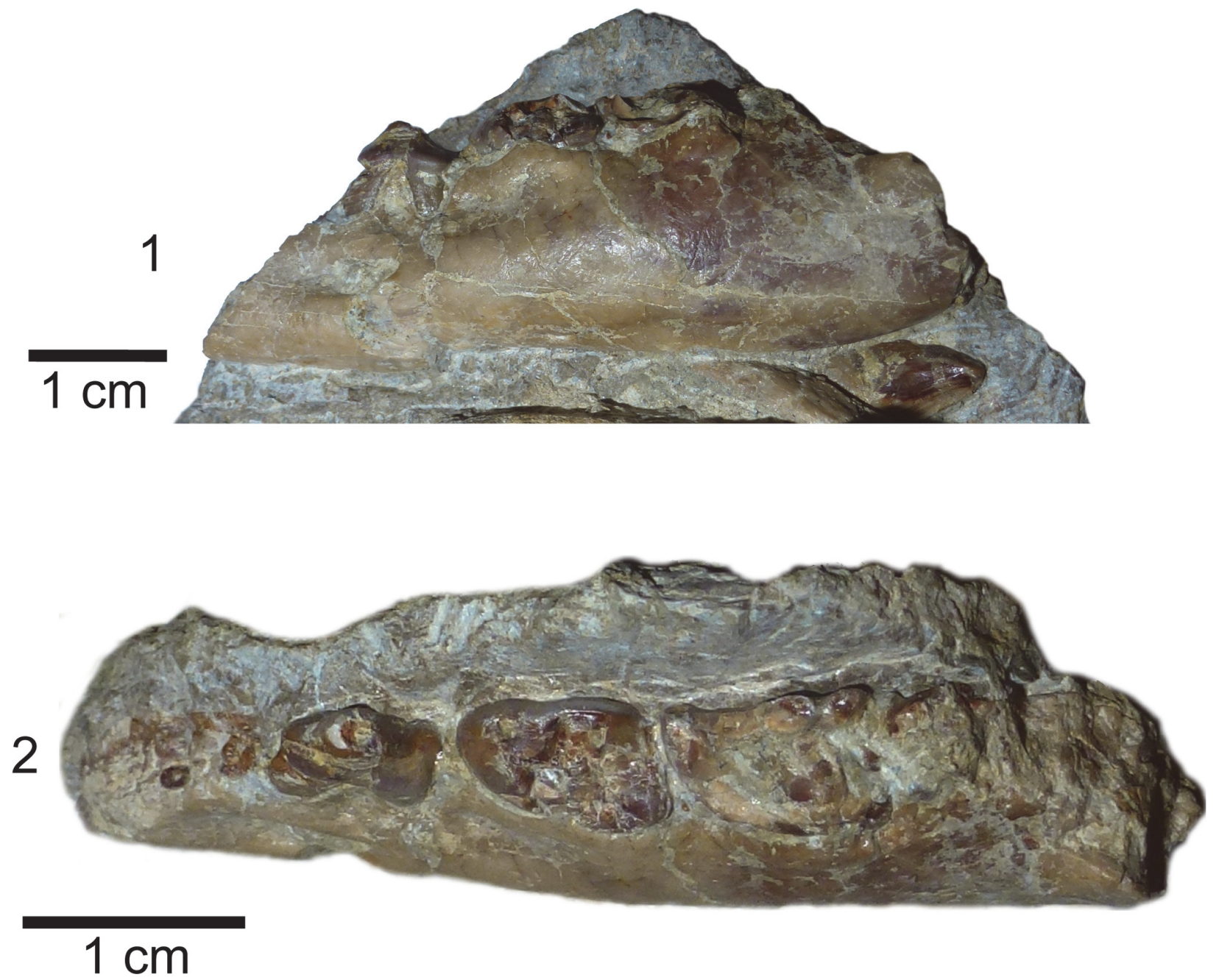

FIGURE 9. Left mandible (SCT 243), Deinogalerix sp. 1, lateral view; 2, dorsal view.

slightly larger than that of $D$. freudenthali (Figure 7).

\section{DISCUSSION}

\section{Interrelations with the Gargano Deinogalerix}

The comparative analyses performed in this study indicate that Deinogalerix samniticus sp. nov. and Deinogalerix sp. from Scontrone differ from all the other species of the genus described so far because of their possessing a small p3 associated with a proportionally much larger $\mathrm{p} 4$ (same size as $\mathrm{m} 1$, see Figure 7.1, Table 3). Deinogalerix sp. is significantly smaller than $D$. samniticus sp. nov. Both could possibly be extreme variants of the same species. Nonetheless, the marked odontometrical difference (roughly $20 \%$ ), which exceeds that between sexes (approximately 10\%) indicated by Butler (1980), but also important morphological distinctions, such as the quite high and rostrally tapering horizontal ramus of Deinogalerix sp., as well as the different features of the trigonid of $\mathrm{m} 1$ in the two species, seem to rule out this possibility. Deinogalerix sp. is distinct from $D$. samniticus $\mathrm{sp}$. nov., but the writers believe that a formal description of another new species based only on a single and badly preserved specimen is impracticable. Based mainly on dimensional criteria, all the remains of Deinogalerix from Scontrone but SCT 243 are attributed to the new species $D$. samniticus sp. nov.

Deinogalerix samniticus sp. nov. is characterized by having $\mathrm{m} 1$ with trigonid enlarged by the mesiolingual bulge of the postparacristid, and M3 with well-developed parastyle and slightly concave labial profile of the paracone, which give the tooth its characteristic profile. A set of dental features near $D$. samniticus sp. nov. to the primitive species of the genus $(D$. masinii and $D$. freudenthali): $\mathrm{p} 4$ with enclosed trigonid compared to more advanced 
species basin, protoconid and metaconid low, and paraconid imperfectly identified; $\mathrm{m} 1$ with talonid slightly larger proportionally than the trigonid; $\mathrm{m} 2$ with robust and complete mesiolabial cingulum; $\mathrm{m} 3$ with well-developed mesiolabial cingulum; P4 with low protocone and hypocone; M3 with acute mesiolabial corner. Another primitive trait is its blunt and low-crowned cusps/ids. In contrast, the small protocone in P3 seems an advanced morphotype of the genus.

Not only Deinogalerix samniticus sp. nov. has features in common with primitive representatives of the genus. Also Deinogalerix sp. shares a primitive character, which is the rostrally tapering horizontal ramus like $D$. masinii. The primitive characters of $D$. samniticus sp. nov. and Deinogalerix sp. are consistent with Scontrone's older age, compared to the Gargano fissure fillings (Mazza and Rustioni, 2008, but see also Freudenthal et al., 2013).

However, despite being the earliest representatives of the genus, the species from Scontrone cannot candidate for direct ancestors of the Gargano species. Morphologically, several primitive features of Deinogalerix samniticus sp. nov. (i.e., proportionally longer talonid in $\mathrm{m} 1$, well-developed mesiolabial cingulum in $\mathrm{m} 2$ and $\mathrm{m} 3$, enclosed trigonid basin in p4, blunt and low-crowned cusps/ ids) do not contrast this possibility.

However, dimensionally, both the species from Scontrone possess a very large $\mathrm{p} 4$, approximating the size of $\mathrm{m} 1$, and a proportionally very small p3 (see Figure 7, Figure 8, Table 3, Table 4, Table 5). In contrast, the Gargano species are characterized by a gradual increase in length from p3 to $\mathrm{m} 1$, which is a typical trait of the galericines that are supposed to be the ancestors of Deinogalerix. Moreover, $D$. samniticus sp. nov. is larger than the most primitive species from Gargano. Therefore, the peculiar relative proportions of $\mathrm{p} 3$, $\mathrm{p} 4$, and $\mathrm{m} 1$, make the Deinogalerix species from Scontrone a very unlikely ancestor to those from Gargano, as this derivation would involve a set of evolutionary inversions. The hypothetical transition from $D$. samniticus sp. nov. and Deinogalerix sp. to the small-sized Gargano species (i.e., $D$. masinii and $D$. freudenthali) imposes a drop in the dimensions of $\mathrm{p} 4$, and the passage to the larger species (i.e., $D$. intermedius and $D$. koenigswaldi) a new growth of p4. At the same time, p3 should grow relatively larger, compared to p4 (Figure 7.2, Table 5). In addition, the small protocone in the P3 of $D$. samniticus sp. nov. might be considered an advanced character weighing against the hypothet- ical derivation of the Gargano species from it. This scenario is quite more complicated than if $D$. samniticus sp. nov. and Deinogalerix sp. were considered sister taxa of the Gargano species.

Based on these lines of evidence, we can speculate that the peculiar proportions of Deinogalerix samniticus sp. nov. and Deinogalerix sp. result from an independent evolutionary path from a close common ancestor which, in turn, is not the forerunner of the Gargano representatives. In contrast, both these hypothetical ancestors probably derived from a mainland ancestral species characterized by a regular increase in length of the teeth from $\mathrm{p} 3$ to $\mathrm{m} 1$.

The presence of two strongly endemized Deinogalerix species at Scontrone, which are not the direct ancestors of the other primitive representatives of the genus, implies that the fossil record from this locality is a late step along what was an already intricate evolutionary pathway. The high diversification of Deinogalerix documented by the earliest fossil records from the Apulia Platform (e.g., Scontrone, M013) allows us to speculate that these animals underwent a strong radiation and possibly had already a (relatively?) long history behind them.

\section{New Insights from the Mental Foramen}

The mental foramen of the Scontrone Deinogalerix and of the other species of Deinogalerix, is a character that has not been given the attention it deserves and that nonetheless offers a helpful clue in the search for the possible continental ancestor of the genus. Deinogalerix has the mental foramen constantly located under the mesial root of the p3, or between the two roots of this tooth. In contrast, its position is highly variable within the galericines. In Parasorex it is more frequently observed under the mesial root of $\mathrm{p} 4$, or between the roots of $\mathrm{p} 3$ and $\mathrm{p} 4$. The foramen often opens more rostrally in Galerix Pomel, 1948 [e.g., Galerix exilis (de Blainville, 1839): see Ziegler, 1983], but its position is also quite variable in this genus (e.g., under the mesial root of p4 in Galerix aurelianensis Ziegler, 1990, see van den Hoek Ostende and Fejfar, 2006; Ziegler, 1990). G. stehlini (direct observation by the writers) and G. exilis (Ziegler 1983) may occasionally show two foramina. In Apulogalerix the mental foramen is positioned approximately like in Parasorex, but the morphotypes with the foramen under p3 are quite less frequent.

We can speculate that the foramen constantly located in rostral position in Deinogalerix is a founder effect, or a by-product of the stretching of 


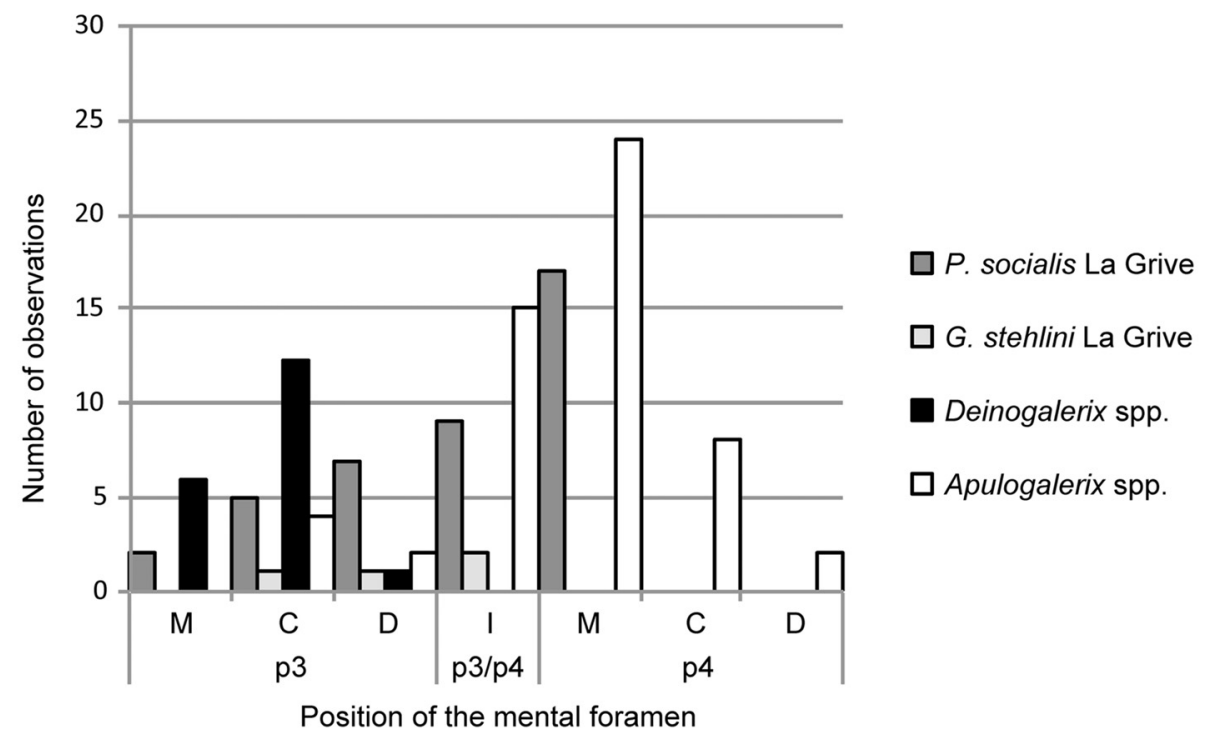

FIGURE 10. Histogram of the positions of the mental foramen in Deinogalerix and in other galericines. $M=$ foramen located under the mesial root of p3 or p4, D = under the distal root of p3 or p4, C ("Central") = between the roots of p3 or p4, I ("Intermediate") = Foramen located between p3 and p4.

the muzzle somehow connected with its evolution in isolation. This second option, however, seems quite unlikely. In spite of the significant elongation of the rostral portion of the mandible from $D$. masinii to $D$. koenigswaldi, which involves, above all, the symphyseal region, the position of the foramen remains unchanged, constantly under $\mathrm{p} 3$. Whereas the $\mathrm{p} 1-\mathrm{p} 2$ diastema progressively stretches, the rear margin of the symphysis is invariably located under the mesial root of $\mathrm{p} 3$.

Actually, very primitive Galericini, such as Eogalericius Lopatin, 2004, and Microgalericulus Lopatin, 2006, from the middle Eocene of Mongolia, often possessed two rostrally-positioned mental foramina, under p3 and/or p2 (Lopatin, 2006). Even if the position of the mental foramen seems variable in the galericines, a foramen constantly located in a rostral position is suggestive of a primitive status for this character. A summary of the different positions of the mental foramen in some of the galericines cited above is reported in Figure 10.

Whether the location of the foramen is inherited, or the result of endemization, it supports the polyphyletic origin of Deinogalerix and Apulogalerix, because in the latter genus the foramen is prevalently located under the mesial root of $\mathrm{p} 4$, as often occurs in Parasorex (Figure 10). This supports van den Hoek Ostende's (2001) and Masini and Fanfani's (2013) supposed derivation of Apulogalerix from a late Miocene Parasorex. At the same time, however, it suggests that Deinogalerix had a distinct and more primitive ancestor.

\section{The Origin of Deinogalerix}

Butler (1980), van den Hoek Ostende (2001), Ziegler (2005), and Villier et al. (2013) addressed the issues of the continental origin of Deinogalerix and of its possible phylogenetic relationships. Butler (1980) favoured the hypothesis that the genus derived from a still unknown gymnure from Asia. Van den Hoek Ostende (2001) suggested that Deinogalerix derived from a middle - late Miocene species of Parasorex, namely $P$. socialis, $P$. iberica, and $P$. depereti, based on a set of common features, which are shared also with Schizogalerix (i.e., hypocone on P3, absence of protoconemetaconule connection in M1-2, p3 larger than p2, p4 with trigonid-like paraconid-protoconid-metaconid complex). Van den Hoek Ostende (2001) underscored that Parasorex and Deinogalerix lack typical synapomorphies of Schizogalerix (i.e., M12 diagonally elongated and with split mesostyle, distal cingulum often connected with entoconid and free posthypocristid in lower molars). According to van den Hoek Ostende (2001, p. 691) "the development of a metastylar crest on the $\mathrm{M} 3$ and a shorter distal arm of the metaconule of the M1 and M2 in Deinogalerix are interpreted as secondary developments." Based on preliminary observations van den Hoek Ostende (2001, p. 691) assumed 
that the "smaller Gargano gymnure" (which is currently ascribed to Apulogalerix Masini and Fanfani, 2013) is sister-taxon to Deinogalerix and affirmed that this solution is the most parsimonious, because it involves only one migration event to the insular domain.

Van den Hoek Ostende's (2001) hypothesis found an apparent later support (van den Hoek Ostende and de Vos in Viller et al., 2013) in the derivation of Apulogalerix from recent (Mammal Neogene faunal zone $10=M N 10$, late Miocene) representatives of Parasorex, as proposed by Masini and Fanfani (2013). In contrast, Ziegler (2005) argued that Deinogalerix stemmed from taxa that had achieved a hypocone-bearing P3 before the appearance of the Parasorex-Schizogalerix clade.

Villier in Villier et al. (2013) contended that the most advanced species of the Parasorex socialis group, e.g., Parasorex ibericus, are more recent, stratigraphically, than the Scontrone Deinogalerix, which at those times was ascribed to $D$. freudenthali. He also shared van den Hoek Ostende's (2001) opinion (i.e., a derivation from Parasorex), but focused on a set of morphological characters of Deinogalerix (i.e., the absence of the paralophid in p4 and the presence, though rare, of a protoconemetaconule connection in $\mathrm{M} 1$, which are interpreted as primitive character states by Villier et al., 2013) to claim the descent of Deinogalerix from earlier representatives than the late Miocene ones supposed by van den Hoek Ostende (2001).

The present detailed analysis of the Scontrone Deinogalerix cannot conclusively settle this question; it nonetheless adds new evidence to the debate. The remnant of paralophid in the mesial part of $\mathrm{p} 4$ in $D$. samniticus sp. nov. suggests the derivation of Deinogalerix from a taxon bearing such structure, as already remarked by van den Hoek Ostende (2001). Nonetheless, some features possessed by the Gargano species of Deinogalerix, but unfortunately not visible in the fragmental Scontrone remains, seem to contrast the supposed stemming of Deinogalerix from the late Miocene Parasorex and to support Villier's (Villier et al., 2013) opinion. The first is the protoconemetaconule connection, which is very rare, but nonetheless present in M1s of Deinogalerix, as noted by Villier et al. (2013). This connection is absent in all the species of Parasorex but Parasorex kostakii Doukas and van den Hoek Ostende, 2006, which is one of the earliest species of the genus (middle Miocene, MN 5). The second feature in contrast with the stemming of Deinogalerix from a late Miocene Parasorex is the continuous distal cingulum in the majority of the M1s and M2s of Deinogalerix, which is a character stressed by Butler (1980) and van den Hoek Ostende (2001). According to Villier et al. (2013), in D. masinii the distal cingulum is discontinuous and the distal arm of the metaconule extends to the disto-labial corner of the tooth, reaching the metastyle. The same pattern is present in Parasorex. Nonetheless, examining the pictures in Villier et al. (2013, figure $3 \mathrm{~g}$, PU128531), the distal arm of the metaconule of M1 seems fused to the wall of the metastylar crest, more lingually than the disto-labial corner of the crown. Furthermore, in Villier (2012, figure 5.18) specimen PU128533 seems to show M1-2 with a distal arm of the metaconule confluent with an uninterrupted distal cingulum. These two specimens indicate that the relationship between the distal arm of the metaconule and the distal cingulum is variable in $D$. masinii, as it is in the whole genus (e.g., Deinogalerix sp. from F9, Figure 4.12 ). The unsteadiness of this feature distinguishes Deinogalerix from the late Miocene representatives of Parasorex. Nonetheless, this trait is included in the variability of Galerix iliensis (Kordikova, 2000). Also the position of the mental foramen contrasts the supposed derivation from a late Miocene Parasorex.

Piecing together the evidence, we support a hypothesis, similar to that proposed by Villier in Villier et al. (2013), in which Deinogalerix likely descended from a still unknown 'Parasorex-like' taxon, more primitive than the late Miocene representatives of this genus. Possible examples of these 'Parasorex-like' species are the MN 5 (early - middle Miocene) Parasorex kostakii, or Galerix iliensis (Kordikova, 2000). The former bears features (e.g., weak protocone-metaconule connection) that Prieto et al. (2012, p. 231) affirmed being primitive traits of that genus, which had previously been believed exclusive to Galerix. Galerix iliensis has characters (i.e., hypocone on P3 and absence of connection between protocone and metaconule) that, in spite of its assignment to Galerix, evoke Parasorex, according to Kordikova (2000) and Doukas and van den Hoek Ostende (2006). Unfortunately, the generic attribution of this speculative ancestor of Deinogalerix to either Galerix or Parasorex is complicated by the imperfect definition of Galerix. Important diagnostic characters of the latter genus, such as the size of $\mathrm{p} 2$, are still unknown in some of its species (e.g., Galerix iliensis).

As a consequence of all this information, the hypothesis of a late Miocene arrival in the insular domain of the presumed common forerunner of 
Deinogalerix and Apulogalerix seems unlikely. The accumulated evidence weakens the assumption that there was a unique event of colonization of the Scontrone-Gargano area (sweepstake dispersal model, as proposed by Freudenthal, 1985; Freudenthal and Martín-Suárez, 2006, 2010; van den Hoek Ostende et al., 2009; Freudenthal et al., 2013). In contrast, the results of this study seem to weigh in favour of a polyphasic mode of colonization, as supposed by Butler (1980), De Giuli et al. (1987), Mazza et al. (1995, 2009), Abbazzi et al. (1996), Mazza and Rustioni (1996, 2008), Masini et al. (2002, 2008, 2010, 2013), Rook et al. (2006), and Savorelli and Masini (2016).

\section{CONCLUSIONS}

Although based on a limited number of remains, the new species from Scontrone, Deinogalerix samniticus sp. nov. and Deinogalerix sp., are warranted by quite distinctive morphologic and morphometric features. Their discovery revives interest in the giant erinaceids of the Apulia Platform, and in particular in their origin. The early Tortonian age of the Scontrone fossil-bearing deposits (Patacca et al., 2008a, 2008b, 2013) makes the species from Scontrone the earliest representatives of these weird erinaceids. However, independently from their stratigraphic location, the Scontrone representatives have characters that rule them out from the direct ancestry of the Gargano lineages. Deinogalerix was supposed to have stemmed either from late Miocene (van den Hoek Ostende, 2001), or from earlier representatives (Villier in Villier et al., 2013) of Parasorex. The results of the present study are in line with the latter hypothesis, indicating that Deinogalerix would have presumably descended from a hypothetical early - middle Miocene 'Parasorex-like' galericine. These results also dispute the assumption of a common origin of the giant Deinogalerix and the small gymnure Apulogalerix from Gargano.

Recent and ongoing studies on the different components of the peculiar Apulia Platform fauna seem confirming asynchronous colonization events (De Giuli et al., 1987; Masini et al., 2002, 2008), which challenge the presumed unique wave of colonization of the area claimed by Freudenthal (1985), Freudenthal and Martín-Suárez (2006, 2010), van den Hoek Ostende et al. (2009), and Freudenthal et al. (2013). The precursor of the hoplitomerycids, for example, is stated to have arrived in Oligocene times (Mazza and Rustioni, 2011; Mazza, 2013b), whereas the forerunners of various micromammals reached the Apulia Plat- form at least in the course of the early Miocene and during the Messinian (Savorelli and Masini, 2016; Savorelli et al., 2016). The results of the present study bring new evidence that calls into question the hypothesis of a late Miocene arrival of the lineage of the giant erinaceid Deinogalerix and seems rather to indicate an early - middle Miocene dispersal.

These discoveries add further tiles to the still imperfect mosaic of the evolution of the Apulia Platform's palaeoinsular fauna. They not only reveal that Deinogalerix had a longer history than previously supposed, they also show that, similar to other taxa of the Apulia Platform, like the ruminant family Hoplitomerycidae (Mazza and Rustioni, 2011; Mazza et al., 2014), this erinaceid was monophyletic and radiated into a set of strongly endemized species.

\section{ACKNOWLEDGEMENTS}

We thank the Superintendent of the Archaeological Superintendency of Abruzzo, A. Pessina, for the casts of the Gargano type specimens, as well as the laboratory technician of the same Superintendency, S. Caramiello, for the restoration of the Scontrone specimens. We are particularly indebted to L. van den Hoek Ostende and B. Villier for critically revising an early version of the manuscript and very much improving it. We also thank $L$. Rook (Florence University, Italy) who provided the facilities and the access to the lab. FFR 2012 (Palermo University) and PAULMAZZARICATEN13 Mazza P. Fondo Ateneo 2013 MIUR (the Italian Ministry of Education, University and Research) grants supported this study.

\section{REFERENCES}

Abbazzi, L., Benvenuti, M., Boschian, G., Dominici, S., Masini, F., Mezzabotta, C., Piccini, L., Rook, L., Valleri, G., and Torre, D. 1996. Revision of the Neogene and Pleistocene of the Gargano region (Apulia, Italy). The marine and continental succession and the mammal faunal assemblages in an area between Apricena and Poggio Imperiale (Foggia). Memorie della Società Geologica Italiana, 51:383-402.

Agustí, J. 1986. Dental evolution in the endemic glirids of the Western Mediterranean islands. Mémoires du Muséum d'Histoire Naturelle de Paris (C), 53:227232.

Butler, P.M. 1980. The giant erinaceid insectivore Deinogalerix Freudenthal from the Upper Miocene of the Gargano, Italy. Scripta Geologica, 57:1-72.

Crochet, J.Y. 1986. Insectivores pliocènes du Sud de la France (Languedoc-Rous-sillon) et du Nord-Est de l'Espagne. Palaeovertebrata,16:145-171. 
de Blainville, H.M.D. 1839. Osteographie des Mammifères. Tome I, Livraison $6-\mathrm{H}$, insectivores. J.B. Bailliere et Fils, Paris.

De Giuli, C., Masini, F., and Valleri, G. 1987. Paleogeographic evolution of the Adriatic area since Oligocene to Pleistocene. Rivista Italiana di Paleontologia e Stratigrafia, 93:109-126.

Doukas, C.S. 1986. The mammals from the Lower Miocene of Aliveri (Island of Evia, Greece). Part 5. The Insectivores. Proceedings Of The Koninklijke Nederlandse Akademie Van Wetenschappen Series BPalaeontology Geology Physics Chemistry Anthropology, 89:15-38.

Doukas, C.S. and van den Hoek Ostende, L..W. 2006. Insectivores (Erinaceomorpha, Soricomorpha, Mammalia) from Karydia and Komotini (Thrace, Greece; MN 4/5). Beitraege zur Palaeontologie, 30:109-131.

Engesser, B. 1980. Insectivora und Chiroptera (Mammalia) aus dem Neogen der Türkei. Schweizerische Palaeontologische Abhandlungen, 102:45-149.

Fischer, G. 1814. Zoognosia tabulis synopticis illustrata. Volumen tertium. Quadrupedum reliquorum. Cetorum et montrymatum descriptionem continens. Nicolai Sergeidis Vsevolozky, Mosquae.

Filhol, H. 1891. Etudes sur les mammifères fossiles de Sansan. Annales des Sciences Géologiques, 21:1315.

Freudenthal, M. 1971. Neogene vertebrates from the Gargano Peninsula, Italy. Scripta Geologica, 3:1-10.

Freudenthal, M. 1972. Deinogalerix koenigswaldi nov. gen., nov. sp., a giant insectivore from the Neogene of Italy. Scripta Geologica, 14:1-19.

Freudenthal, M. 1976. Rodent stratigraphy of some Miocene fissure fillings in Gargano (prov. Foggia, Italy). Scripta Geologica, 27:1-23.

Freudenthal, M. 1985. Cricetidae (Rodentia) from the Neogene of Gargano (prov. Foggia, Italy). Scripta Geologica, 77:29-75.

Freudenthal, M. and Martín-Suárez, E. 2006. Gliridae (Rodentia, Mammalia) from the late Miocene fissure filling Biancone 1 (Gargano, prov. Foggia, Italy). Palaeontologia Electronica, 9:1-23.

Freudenthal, M. and Martín-Suárez, E. 2010. The age of immigration of the vertebrate faunas found at Gargano (Apulia, Italy) and Scontrone (l'Aquila, Italy). Comptes Rendus Palevol, 9:95-100. doi:10.1016/j.crpv.2009.12.004.

Freudenthal, M., van den Hoek Ostende, L. and MartínSuárez, E. 2013. When and how did the Mikrotia fauna reach Gargano (Apulia, Italy)? Geobios, 46:105-109. doi:10.1016/j.geobios.2012.10.004

Gould, G. 1995. Hedgehog Phylogeny (Mammalia, Erinaceidae)-the Reciprocal Illumination of the Quick and the Dead. American Museum Novitates, 3131:145.

Kordikova, E. 2000. Insectivora (Mammalia) from the Lower Miocene of the Aktau Mountains, South-East- ern Kazakhstan. Senckenbergiana lethaea, 80:6779. doi:10.1007/bf03043665.

Linnaeus, C. 1758. Systema Naturae, 10th Edition; Volume 1. G. Engelman, Leipzig.

Lopatin, A. 2006. Early Paleogene insectivore mammals of Asia and establishment of the major groups of Insectivora. Paleontological Journal 40:S205-S405. doi:10.1134/s0031030106090012.

Masini, F., Bonfiglio, L., Petruso, D., Marra, A.C., Abbazzi, L., Delfino, M., Fanfani, F., and Torre, D. 2002. The role of coastal areas in the Neogene-Quaternary mammal island populations of central Mediterranean. Biogeographia, 23:165-189.

Masini, F. and Fanfani, F. 2013. Apulogalerix pusillus nov. gen., nov. sp., the small-sized Galericinae (Erinaceidae, Mammalia) from the "Terre Rosse" fissure filling of the Gargano (Foggia, South-Eastern Italy). Geobios, 46:89-104. doi:10.1016/j.geobios.2012.10.008.

Masini, F., Petruso, D., Bonfiglio, L., and Mangano, G. 2008. Origination and extinction patterns of mammals in three central Western Mediterranean islands from the Late Miocene to Quaternary. Quaternary International, 182:63-79. doi:10.1016/j.quaint.2007.09.020.

Masini, F., Rinaldi, P.M., Petruso, D., and Surdi, G. 2010. The Gargano Terre Rosse insular faunas: An overview. Rivista Italiana di Paleontologia e Stratigrafia, 116:421-435.

Masini, F., Rinaldi, P., Savorelli, A., and Pavia, M. 2013. A new small mammal assemblage from the M013 Terre Rosse fissure filling (Gargano, South-Eastern Italy). Geobios, 46:49-61. doi:10.1016/j.geobios.2012.10.003.

Mazza, P. 2013a. The systematic position of Hoplitomerycidae (Ruminantia) revisited. Geobios, 46:33-42.

Mazza, P. 2013b. Hoplitomerycidae (Ruminantia; Late Miocene, Central-Southeastern Italy): Whom and where from? Geobios, 46:511-520. doi:10.1016/j.geobios.2013.08.001

Mazza, P., Delfino, M., van den Hoek Ostende, L.W. Masini, F., Pavia, M., Rinaldi, P.M., and Rustioni, M. 2009. How, when and where from of the AbruzzoApulian palaeofauna, p. 57-60. In Fanti, F. and Spalletta, C. (eds.), International Conference of Vertebrate PalaeoBiogeography. Abstract Book, Bologna.

Mazza, P., Rossi, M., and Agostini, S. 2014. Hoplitomerycidae (Late Miocene, Italy), an Example of Giantism in Insular Ruminants. Journal of Mammalian Evolution, 22:271-277. doi:10.1007/s10914-014-9277-2.

Mazza, P. and Rustioni, M. 1996. The Turolian artiodactyls from Scontrone (Abruzzi, central Italy). Bollettino Società Paleontologia Italiana, 35:93-106.

Mazza, P. and Rustioni, M. 2008. Processes of island colonization by Oligo-Miocene land mammals in the central Mediterranean: New data from Scontrone 
(Abruzzo, Central Italy) and Gargano (Apulia, Southern Italy). Palaeogeography, Palaeoclimatology, Palaeoecology, 267:208-215. doi:10.1016/j.palaeo.2008.06.018.

Mazza, P. and Rustioni, M. 2011. Five new species of Hoplitomeryx from the Neogene of Abruzzo and Apulia (central and southern Italy) with revision of the genus and of Hoplitomeryx matthei Leinders, 1983. Zoological Journal of the Linnean Society, 163:13041333. doi:10.1111/j.1096-3642.2011.00737.x.

Mazza, P., Rustioni, M., Aruta, G., and Di Carlo, E. 1995. A Messinian Prolagus from Capo di Fiume Quarry (Palena, Abruzzo, Central Italy). Bollettino della Società Paleontologica Italiana, 34:55-66.

McKenna, M., Bell, S., and Simpson, G. 1997. Classification of Mammals Above the Species Level. Columbia University Press, New York.

Mein, P. and Martín-Suárez, E. 1993. Galerix iberica sp. nov. (Erinaceidae, Insectivora, Mammalia) from the Late Miocene and Early Pliocene of the Iberian Peninsula. Geobios, 26:723-730. doi:10.1016/s0016-6995(93)80055-v.

Novacek, M.J. 1986. The skull of leptictid insectivorans and the higher-level classification of eutherian mammals. Bulletin of the American Museum of Natural History, 183:1-112.

Patacca, E., Scandone, P., and Carnevale, G. 2013. The Miocene vertebrate-bearing deposits of Scontrone (Abruzzo, Central Italy): Stratigraphic and paleoenvironmental analysis. Geobios, 46:5-23. doi:10.1016/j.geobios.2012.11.001.

Patacca, E., Scandone, P., and Mazza, P. 2008a. The Miocene land-vertebrate fossil site of Scontrone (Central Apennines). Bollettino della Società Geologica Italiana, 127:51-73.

Patacca, E., Scandone, P., and Mazza, P. 2008b. Oligocene migration path for Apulia macromammals: the Central-Adriatic bridge. Bollettino della Società Geologica Italiana, 127:337-355.

Pavia, G., Bertok, C., Ciampo, G., Di Donato, V., Martire, L., Masini, F., Pavia, M., Santangelo, N., Taddei Ruggiero E., and Zunino, M. 2010. Tectono-sedimentary evolution of the Pliocene to Lower Pleistocene succession of the Apricena-Lesina-Poggio Imperiale quarrying district (western Gargano, southern Italy). Italian Journal of Geosciences, 129:132-155.

Pomel, A.N. 1848. Etudes sur les carnassiers insectivores (extrait). Seconde partie, Classification des insectivores. Archives des Sciences Physiques et Naturelles, 9:244-251.

Prieto, J., Gross, M., Böhmer, C., and Böhme, M. 2010. Insectivores and bat (Mammalia) from the late Middle Miocene of Gratkorn (Austria): biostratigraphic and ecologic implications. Neues Jahrbuch für Geologie und Paläontologie - Abhandlungen, 258:107-119. doi:10.1127/0077-7749/2010/0088.
Prieto, J., Hoek Ostende, L., and Hír, J. 2012. The Middle Miocene insectivores from Sámsonháza 3 (Hungary, Nógrád County): Biostratigraphical and palaeoenvironmental notes near to the Middle Miocene Cooling. Bulletin of Geosciences, 227-240. doi:10.3140/bull.geosci.1296.

Rook, L., Gallai, G., and Torre, D. 2006. Lands and endemic mammals in the Late Miocene of Italy: Constrains for paleogeographic outlines of Tyrrhenian area. Palaeogeography, Palaeoclimatology, Palaeoecology, 238:263-269. doi:10.1016/j.palaeo.2006.03.027.

Savorelli, A., Colombero, S., and Masini, F. 2016. Apatodemus degiulii $\mathrm{n}$. gen. et sp. (Rodentia, Muridae), a hitherto undescribed endemite from the Terre Rosse of Gargano (Late Miocene, Southeastern Italy). Paläontographica Abteilung A, 306:25-49.

Savorelli, A. and Masini, F. 2016. Mystemys giganteus nov. gen. nov. sp.: an enigmatic and rare cricetid from the Terre Rosse M013 fissure filling (Gargano, Southeastern Italy). Paläontographica Abteilung A, 306:1-23.

Valleri, G. 1984. New data on Planktonic Foraminifera biostratigraphy from the Neogene of the Gargano Peninsula (Foggia, Southern Italy). Rivista Italiana di Paleontologia e Stratigrafia, 90:375-406.

van den Hoek Ostende, L. 2001. A revised generic classification of the Galericini (Insectivora, Mammalia) with some remarks on their palaeobiogeography and phylogeny. Geobios, 34:681-695. doi:10.1016/s0016-6995(01)80029-2.

van den Hoek Ostende, L. and Fejfar, O. 2006. Erinaceidae and Talpidae (Erinaceomorpha, Soricomorpha, Mammalia) from the Lower Miocene of Merkur-Nord (Czech Republic, MN 3). Beitraege zur Palaeontologie, 30:175-203.

van den Hoek Ostende, L., Meijer, H., and van der Geer, A. 2009. A bridge too far. Comment on "Processes of island colonization by Oligo-Miocene land mammals in the central Mediterranean: New data from Scontrone (Abruzzo, Central Italy) and Gargano (Apulia, Southern Italy)" by P.P.A. Mazza and M. Rustioni [Palaeogeography, Palaeoclimatology, Palaeoecology 267 (2008) 208-215]. Palaeogeography, Palaeoclimatology, Palaeoecology, 279:128-130. doi:10.1016/j.palaeo.2009.02.029.

Villier, B. 2012. The anatomy of Deinogalerix and systematics of the Galericini. Unpublished PhD Thesis, University of Turin, Turin, Italy.

Villier, B. and Carnevale, G. 2013. A new skeleton of the giant hedgehog Deinogalerix from the Miocene of Gargano, southern Italy. Journal of Vertebrate Paleontology, 33:902-923. doi:10.1080/02724634.2013.743897.

Villier, B., van Den Hoek Ostende, L., De Vos, J., and Pavia, M. 2013. New discoveries on the giant hedgehog Deinogalerix from the Miocene of Gargano (Apulia, Italy). Geobios, 46:63-75. doi:10.1016/j.geobios.2012.10.001. 
Von Meyer, C.E.H.1865. Briefe an den Herausgeber. Neues Jahrbuch für Mineralogie, Geologie und Paläontologie, 1865:215-221.

Waddell, J., Okada, N., and Masami, P. 1999. Towards resolving the interordinal relationships of placental mammals. Systematic Biology, 48:1-5. doi:10.1080/106351599260391.

Ziegler, R. 1983. Odontologische und osteologische Untersuchungen an Galerix exilis (Blainville) (Mammalia, Erinaceidae) aus dem miozänen Ablagerungen von Steinberg und Goldberg im Nördlinger Ries (Süd-Deutschland). Unpublished PhD Thesis, Universität München, München, Germany.
Ziegler, R. 1990. Didelphidae, Erinaceidae, Metacondontidae und Dimylidae (Mammalia) aus dem Oberoligozän und Untermioztän Süddeutschlands. Stuttgarter Beiträge zur Naturkunde, B 158:1-99.

Ziegler, R. 2005. Erinaceidae and Dimylidae (Lipotyphla) from the Upper Middle Miocene of South Germany. Senckenbergiana lethaea, 85:131-152. doi:10.1007/bf03043423.

Zijlstra, J. and Flynn, L. 2015. Hedgehogs (Erinaceidae, Lipotyphla) from the Miocene of Pakistan, with description of a new species of Galerix. Palaeobiodiversity and Palaeoenvironments, 95:477-495. doi:10.1007/s12549-015-0190-3. 